\title{
Environmental risks and toxicity of surfactants: overview of analysis, assessment, and remediation techniques
}

\author{
Suaibu O. Badmus ${ }^{1} \cdot$ Hussein K. Amusa ${ }^{2} \cdot$ Tajudeen A. Oyehan $^{1} \cdot$ Tawfik A Saleh $^{3}$ \\ Received: 22 June 2021 / Accepted: 7 September 2021 / Published online: 29 September 2021 \\ (C) The Author(s), under exclusive licence to Springer-Verlag GmbH Germany, part of Springer Nature 2021
}

\begin{abstract}
This work comprehensively reviewed the toxicity and risks of various surfactants and their degraded products in the environmental matrices, various analytical procedures, and remediation methods for these surfactants. The findings revealed that the elevated concentration of surfactants and their degraded products disrupt microbial dynamics and their important biogeochemical processes, hinder plant-surviving processes and their ecological niche, and retard the human organic and systemic functionalities. The enormous adverse effects of surfactants on health and the environment necessitate the need to develop, select, and advance the various analytical and assessment techniques to achieve effective identification and quantification of several surfactants in different environmental matrices. Considering the presence of surfactants in trace concentration and environmental matrices, excellent analysis can only be achieved with appropriate extraction, purification, and preconcentration. Despite these pretreatment procedures, the chromatographic technique is the preferred analytical technique considering its advancement and shortcomings of other techniques. In the literature, the choice or selection of remediation techniques for surfactants depends largely on eco-friendliness, cost-implications, energy requirements, regeneration potential, and generated sludge composition and volume. Hence, the applications of foam fractionation, electrochemical advanced oxidation processes, thermophilic aerobic membranes reactors, and advanced adsorbents are impressive in the clean-up of the surfactants in the environment. This article presents a compendium of knowledge on environmental toxicity and risks, analytical techniques, and remediation methods of surfactants as a guide for policymakers and researchers.
\end{abstract}

Keywords Ionic surfactants $\cdot$ Non-ionic surfactants $\cdot$ Ecotoxicity $\cdot$ Environmental matrix $\cdot$ Remediation

\section{Introduction}

Surfactants are among the most challenging emerging contaminants which are continuously discharged into the environment through wastewater treatment plants (WWTPs). Surfactants possess both hydrophilic (polar charged or uncharged head group) and hydrophobic (non-polar hydrocarbon tail) and thus are regarded as amphipathic molecules (Mungray and Kumar

Reaponsible Editor: Ester Heath

Tawfik A Saleh

tawfik@kfupm.edu.sa

1 Center for Integrative Petroleum Research, King Fahd University of Petroleum \& Minerals, 31261 Dhahran, Saudi Arabia

2 Department of Chemical Engineering, King Fahd University of Petroleum \& Minerals, Dhahran 31261, Saudi Arabia

3 Department of Chemistry, King Fahd University of Petroleum \& Minerals, Dhahran 31261, Saudi Arabia
2009). Surfactants are employed for various domestic and industrial applications due to their unique physicochemical properties (Ramprasad and Philip 2016; Collivignarelli et al. 2019). However, the persistence of the transformed products in an environment is of great concern to environmental sustainability and healthy ecosystems (Ivanković and Hrenović 2010; Nascimento et al. 2019; Liu et al. 2021; Li et al. 2021; Yao et al. 2021 ; Hao et al. 2021).

In perspective, surfactants are essential for the industrial production of detergents, textiles, paints, polymers, pharmaceuticals, pesticides, paper, and personal care products. These surfactants could reduce interfacial tension and stabilize foams and or emulsions; hence, they are significant for certain essential operations such as oil recovery and mining (Srinet et al. 2017; Zanoletti et al. 2017; Moura et al. 2019). For example, benzalkonium chloride and alkylbenzene linear sulfonate are employed to produce laundry detergents, personal care, and textiles softeners (Watson et al. 2012; Brycki et al. 2017; Moura et al. 2019). Also, hexadecyltrimethylammonium 
bromide helps in the impregnation of polyelectrolyte multilayer films to enhance its antimicrobial efficacy and buffer constituents for successful DNA extraction (Cloutier et al. 2015; Rawat et al. 2016).

The global market size of surfactants is currently about 42.1 billion US dollars, and it is projected to reach $\$ 52.4 \mathrm{bn}$ by 2025 (Fig. 1). This conservative estimate would likely be exceeded with the global increase in production and use of hand sanitizers due to the COVID-19 pandemic. As shown in Fig. 1, ionic (anionic, cationic, and amphoteric) surfactants constitute $65 \%$ of surfactants' global market size. Surfactants are categorized into five groups based on the type of charge on hydrophilic groups, and these include anionic, cationic, non-ionic, semi-polar, and amphoteric. Cationic surfactants possess a cationic functional group, while anionic surfactants contain negatively charged hydrophilic functional groups (Zhu et al. 2018). The non-ionic surfactants (TAS) possess a non-ionized hydrophilic group(s), while the charge on the hydrophilic sites of amphoteric surfactants changes as a function of pH (Fei et al. 2018; Collivignarelli et al. 2019). Fig. 2 shows the chemical structures of standard surfactant classes and examples. The linear alkylbenzene sulfonate (LABS), alkyl ethoxy sulphate (AES), alkyl sulphate (AS), alkylphenol ethoxylate (APE), alkyl ethoxylates (AE), and quaternary ammonium-based structures (QAC) are the most sourced and used surfactants globally (Borghi et al. 2011; Kruszelnicka et al. 2019).

Owing mainly to the extensive applications of surfactants, their huge concentration from mostly urban or industrial and domestic wastewater can end up in municipal wastewater treatment plants (MWTPs) or directly discharge into the environment (Bautista-Toledo et al. 2014; Camacho-Muñoz et al. 2014). Several years ago, it was estimated that surfactants in domestic and industrial wastewater are between 1 to $10 \mathrm{mg} / \mathrm{L}$ and $300 \mathrm{mg} / \mathrm{L}$, respectively (Zhang et al. 1999). There are chances that surfactants can penetrate drinking water through MWTPs, thereby posing a health risk to human, animal, and aquatic lives (Bautista-Toledo et al. 2008). Also, the fate and chemical structure of surfactants, environmental systems (aerobic or anaerobic), and electron acceptors contributes mainly to the persistence, degradability, and ecological effects of surfactants in the environment (Bering et al. 2018; Zhu et al. 2018).

Some of the commercially available surfactants pose a severe environmental and public threat to humans and ecosystems. For instance, anionic surfactants, predominantly linear alkylbenzene sulfonates (LAS), cause biochemical, pathological, physiological, and other impacts on aquatic/terrestrial ecosystems (Petrie et al. 2015; Zhu et al. 2018). Also, LAS causes skin irritation and respiratory problems (Collivignarelli et al. 2019) and reduces the resistance of aquatic biota against environmental stress, reproduction, and growth processes (Hampel et al. 2012; Moura et al. 2019). Surfactants usually increase the solubility of contaminants and thus facilitate eutrophication (Zanoletti et al. 2017). Also, the increasing hydrophobic properties of the surfactants proportionally increase their toxicity (Borghi et al. 2011). These vast impacts consequently raise public health and environmental concern about the high concentration of surfactants.

Conventionally, various techniques have been deployed to decontaminate surfactants from wastewater. Some of these remediation technologies include physicochemical processes, membrane filtration and flocculation-adsorption, ultrafiltration, electrocoagulation, and chemical and electro-oxidation (Rodriguez Boluarte et al. 2016; Gönder et al. 2017; Mohammadi et al. 2017; Pinto et al. 2017). However, when the concentrations of surfactants in wastewaters are high, nearly all traditional techniques failed to comprehensively
Fig. 1 The recent and projected global market of surfactant types (Sources: marketsandmarkets. com and alliedmarketresearch. com)

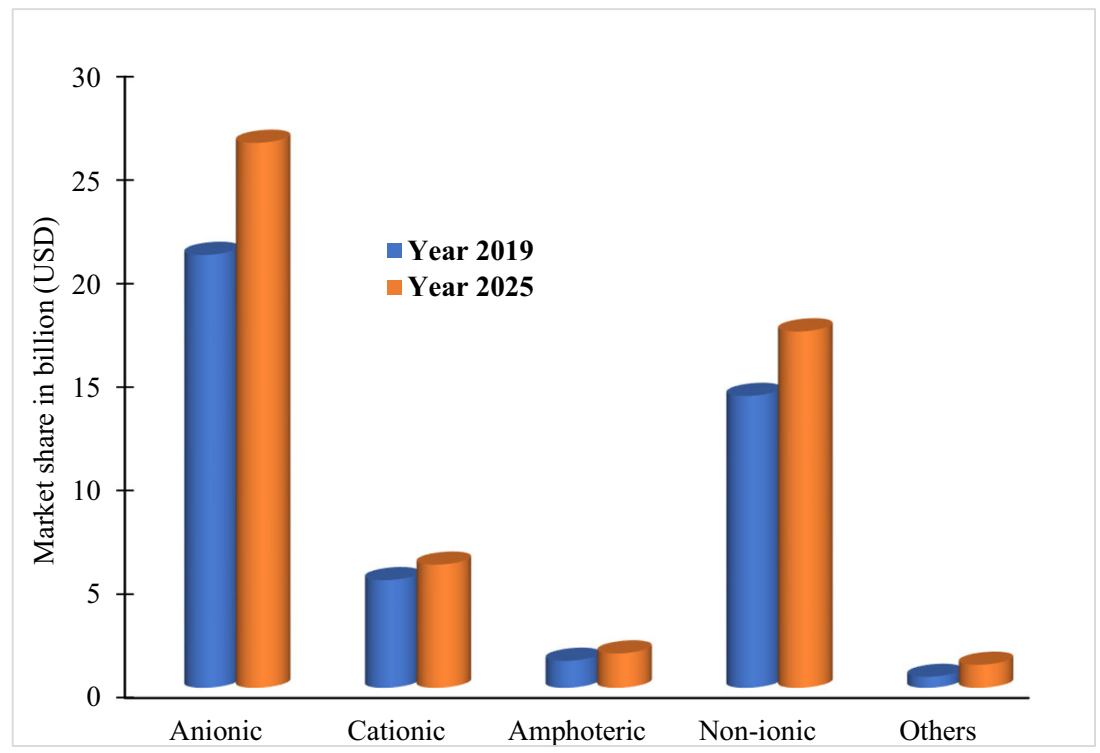


Fig. 2 Chemical structures of typical surfactants showing the hydrophilic head and their corresponding hydrophobic tail. a Nonylphenol ethoxylate, a nonionic surfactant. b Ammonium lauryl sulphate, an anionic surfactant. c Benzethonium (chloride), a cationic surfactant. $\mathbf{d}$ Lauramidopropyl betaine, a zwitterion (amphoteric). (a)

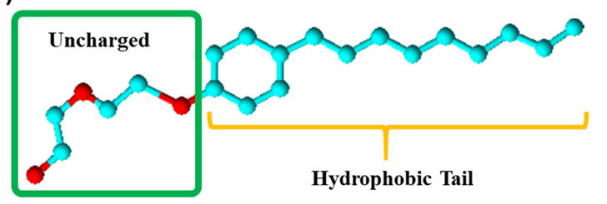

(c)

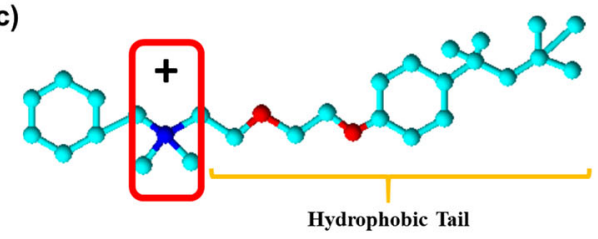

(b)

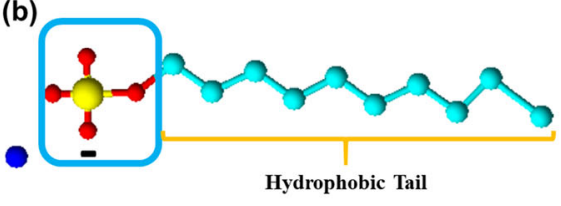

(d)

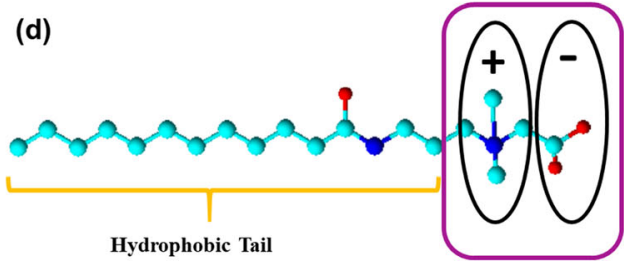

remove surfactants contamination (Sirés and Brillas 2012; Palmer and Hatley 2018). In general, the selection of efficient treatment technologies largely depends on the influent and effluent quality.

The physicochemical treatment technologies possess excellent removal efficiencies with some notable challenges. For instance, nearly all physical and chemical treatments require high capital cost and retention time and generate sludges (Jain et al. 2017; Palmer and Hatley 2018). However, physical treatment requires fewer chemical and operational inputs, while chemical treatment generates low sludge. On the other hand, the ease of operation, low cost, and removal efficiency position biological treatment unit and cyclic activated sludge system as a better remediation approach for surfactants (Taghavi et al. 2017; Zhu et al. 2018; Moura et al. 2019). However, the high retention time, foam formation, death of biomass, and massive sludge generation reduce the biological treatment's acceptance and applicability (Zhu et al. 2018). Previous studies have proven that the use of thermophilic organisms can reduce operational costs and sludge generation and thus increase the adoption of biological treatment (Collivignarelli et al. 2017, 2019).

Adsorption is widely accepted due to its excellent efficiency, ease of operation and modification of adsorbents, costeffectiveness, and eco-friendliness (Saleh 2021; Saleh 2020a, b, c; Valizadeh et al. 2016; Zanoletti et al. 2017). Previously, carbon nanotubes (Ncibi et al. 2015), polymer resin (Gönder et al. 2017), fly ash- $\mathrm{TiO}_{2}$, coal fly ash (Zanoletti et al. 2017), and amino crosslinked chitosan microspheres (Zhang et al. 2017) were employed in the removal of surfactants. However, activated carbon remains the most suitable candidate among many developed adsorbents for removing surfactants from wastewater (Valizadeh et al. 2016). Still, concerted efforts are necessary for developing advanced adsorbents with exceptional surfactants removal efficiencies without compromising environmental and public health safety.

This article comprehensively examined the ecotoxicity and health implications of surfactants and their transformed or degraded products. Also, various analytical and remediation techniques were carefully discussed owing largely to the enormous environmental risks and concerns of surfactants. Then, the research gaps and prospects in surfactants were highlighted for future studies.

\section{Environmental risks and toxicity of surfactants}

Previous studies have shown that a high concentration of surfactants, and their degraded products are deposited into various environmental compartments due to their extensive applications (Olkowska et al. 2014). The surfactants can enter the environment from the effluents generated in agrochemical products, industrial products, and domestic activities and consequently cause environmental pollution (Li et al. 2018b). For instance, biocides, herbicides, and pesticides are among the agrochemicals, while personal care products, emulsifiers, wetting agents, detergents, and coating or softening of fabric, paper, and carpets are notable industrial products that continuously contribute to the surfactants-aided environmental pollution. Also, laundry, disinfection, and fumigation are major domestic activities that release surfactants to the environment.

The fate, distribution, and persistence of surfactants in the environment are mainly influenced by sorption and bio-/ photodegradation (Lara-Martín et al. 2012). These processes depend primarily on various environmental factors such as $\mathrm{pH}$, temperature, and salinity.

The municipal wastewater treatment plants usually receive a high concentration of surfactants but release a low concentration of the surfactants and their degraded products upon secondary treatment. The proportion of the post-treatment surfactants and by-products released depends more on the efficiency of MWWTPs (Lara-Martín et al. 2012; CamachoMuñoz et al. 2014; Olkowska et al. 2014).

The transformed products of sulfophenyl carboxylic acids, nonylphenol ethoxylates, octylphenol ethoxylates, and nonylphenol carboxylic acids were recently reported (Li 
et al. 2018b). Notably, nonyl- or octylphenol ethoxylates (NPEOs) are more toxic than their precursors, i.e. alkylphenol (APs) (Lara-Martín et al. 2012; Jardak et al. 2016). Several studies have shown severe ecological and health impacts of toxic surfactants on humans, other vertebrates, soil fauna, microorganisms, crustacean, and terrestrial plants (Domene et al. 2009; Gheorghe et al. 2013). The critical criteria to assess the environmental risks associated with the commercially available surfactants are photo- or biodegradability, toxicity behaviour, and sorption efficiency (Gheorghe et al. 2013). For instance, the surfactants' foam formation and sedimentation deteriorate water quality by reducing air or water oxygen transfer and self-cleaning river capacity, to different extents for different surfactant classes (Gheorghe et al. 2013). Also, surfactants enhance the solubility of persistent organic pollutants (POPs) in the aqueous phase, and the resultant products of aerosol and surfactants significantly impact the atmosphere and climate (Olkowska et al. 2014). The changes in the physiological and biochemical activities of aquatic organisms by LAS delay their metabolism and growth, damage cell membrane, and cause breakage of chlorophyll protein complex (Larson et al. 1993; Koparal et al. 2006)

According to the Registration, Evaluation, Authorisation and Restriction of Chemicals (REACH) Regulation, the ecotoxicity of surfactants can be evaluated with microbiotests (QSAR, ECOSAR) (Lewis and Lewis 2018). The procedures employ the tests such as Daphtoxkit F, Daphnia IQ Test, Rotokit F/M, Ceriodaphtoxit K, Ostracod toxkit, Algal toxkit F, and Microtoxkit. The past studies showed that the surfactants toxicity could be influenced by physicochemical properties of water (i.e. pH, DO, suspended matter), surfactants (i.e. type and concentration and the absorption capacity of surfactants), and biotic factors (the age and type of species, sensitivity between species and their acclimatization) (Garcia et al. 2008; Yamane et al. 2008; Ivanković and Hrenović 2010)

The median effective concentration (EC50) and median growth inhibition concentration (IC50) respectively determine the risk and toxicity of surfactants on animals, plants, and microorganisms. For instance, Ge et al. (2010) discovered that the $96 \mathrm{~h}$ EC50 of acetyl trimethyl ammonium chloride on the green microalgae Chlorella vulgaris is $145 \pm 13.35 \mu \mathrm{g} / \mathrm{L}$, while EC50 of benzalkonium to invertebrates is $5.90 \mu \mathrm{g} / \mathrm{L}$ (Van De Voorde et al. 2012). Also, the IC50 of benzyldimethyldodecylammonium chloride to bacteria is $170.0 \mu \mathrm{g} / \mathrm{L}$ (Di Nica et al. 2017).

Surfactants can retard microbial growth and increase microbial mutation and mortality (Ivanković and Hrenović 2010; Gheorghe et al. 2013). For instance, nonylphenol ethoxylates (NPEOs) can uncouple energy production which can consequently disrupt microbial growth and nitrification processes (Argese et al. 1994). Also, anionic surfactants disrupt internal structures and microbial functions such as environmental resistance, growth, competitive stress, and reproduction (Hampel et al. 2012). The absorption of surfactants by a microorganism can depolarize microbial cell membrane and decrease the absorption of nutrients, acceptance of oxygen, and release of the toxic metabolites (Domene et al. 2009).

Some surfactants have severe health implications on humans through ingestion or drinking of contaminated food items. For example, surfactants react with existing protein in the liver and serum, thus causing long-term metabolic effects and disruption of the human endocrine (Borghi et al. 2011; Gheorghe et al. 2013). Likewise, some surfactants have been reported to cause human skin burning or irritation and eye and respiratory problems (Ying 2006). Alkylphenol ethoxylates and carboxylates retard subsurface penetration of pharmaceutical compounds. Nonylphenol ethoxylates have estrogenic effects on amphibians, mammals, and Pisces (De La Fuente et al. 2010; Borghi et al. 2011). Some surfactants such as LAS damage the root cell membrane and change the membrane structure. Consequently, it impaired the transpiration and translocation of essential nutrients and water (Jardak et al. 2016) (Table 1).

\section{Analysis of surfactants}

Owing to the risks posed by surfactants and their degraded products to the environment, it is pertinent to determine their concentrations in environmental matrices. However, laboratory analysis of surfactants could be a difficult task to accomplish. The reason is that surfactants are usually found in mixtures comprising different components such as isomers, homologues, and other impurities (Lara-Martín et al. 2012). In addition to this, surfactants are often present in trace amounts typically below the analytical instruments' detectable limits. The complexity and variety of matrices in which surfactants naturally occur additionally complicate and hinder their analysis. To this end, a sophisticated state-of-the-art technique is required to carry out surfactant analysis in aqueous streams. Table 2 summarizes the analytical techniques often employed in the open literature.

One of the strategies to overcome the above-stated analytical challenges for practical surfactant analysis is to perform extraction before analysis. Other vital approaches are sample purification and preconcentration. Extensive independent research and reviews have been conducted on the extraction, isolation, and preconcentration of surfactants (Kurrey et al. 2019; Yamini et al. 2019; Nasiri et al. 2020). Based on the literature survey, solid-phase extraction (SPE) is described as the most versatile pre-treatment method due to its numerous advantages (Gao et al. 2014, 2020).

Surfactants are usually identified using several techniques such as spectrophotometry, titrimetry, and chromatography (Cierniak et al. 2020). If the surfactant is present as a single 
Table 1 Application and environmental risks of surfactants

\begin{tabular}{|c|c|c|c|c|}
\hline $\begin{array}{l}\text { Surfactants in } \\
\text { environmental } \\
\text { matrix }\end{array}$ & $\begin{array}{l}\text { Classes of } \\
\text { surfactants }\end{array}$ & Uses/applications & Risks & Comment \\
\hline $\begin{array}{l}\text { Linear alkyl } \\
\text { benzene } \\
\text { sulfonates }\end{array}$ & Anionic & $\begin{array}{l}\text { Detergent formulation } \\
\text { and personal care } \\
\text { products }\end{array}$ & $\begin{array}{l}\text { Non-conservative } \\
\text { behaviour }\end{array}$ & $\begin{array}{l}\text { Excellent } \\
\text { cleaning } \\
\text { properties, low } \\
\text { cost }\end{array}$ \\
\hline $\begin{array}{l}\text { Perfluorinated } \\
\text { surfactants }\end{array}$ & Anionic & $\begin{array}{l}\text { Coating of textile, paper } \\
\text { and carpets, } \\
\text { firefighting chemical, } \\
\text { consumer products like } \\
\text { floor polishes and } \\
\text { shampoos }\end{array}$ & $\begin{array}{l}\text { Persistence, } \\
\text { recalcitrance, and } \\
\text { toxicity }\end{array}$ & $\begin{array}{l}\text { Extensive } \\
\text { production; } \\
\text { required } \\
\text { efficient } \\
\text { treatment } \\
\text { technologies }\end{array}$ \\
\hline $\begin{array}{l}\text { Quaternary } \\
\text { ammonium } \\
\text { ethoxylates } \\
\text { and } \\
\text { cetrimonium } \\
\text { chloride }\end{array}$ & Cationic & $\begin{array}{l}\text { Fabric softening, } \\
\text { disinfectants, hair } \\
\text { conditioning, cosmetic } \\
\text { industry, biocides, and } \\
\text { wetting agents }\end{array}$ & $\begin{array}{l}\text { Very toxic in the } \\
\text { environment }\end{array}$ & $\begin{array}{l}\text { Irreplaceable for } \\
\text { some } \\
\text { industrial uses }\end{array}$ \\
\hline $\begin{array}{l}\text { Alkylphenol } \\
\text { ethoxylates }\end{array}$ & $\begin{array}{l}\text { Non-ionic } \\
\text { surfac- } \\
\text { tants }\end{array}$ & $\begin{array}{l}\text { Detergent, emulsifier, and } \\
\text { wetting agent }\end{array}$ & $\begin{array}{l}\text { Degraded and } \\
\text { transformed products } \\
\text { (nonyl-/octylphenol } \\
\text { ethoxylates) are toxic } \\
\text { as well as persistent in } \\
\text { the environment }\end{array}$ & $\begin{array}{l}\text { Replaced with } \\
\text { better or } \\
\text { eco-friendly } \\
\text { surfactant } \\
\text { (AEOS) }\end{array}$ \\
\hline $\begin{array}{l}\text { Alcohol } \\
\text { ethoxylates }\end{array}$ & $\begin{array}{l}\text { Non-ionic } \\
\text { surfac- } \\
\text { tants }\end{array}$ & $\begin{array}{l}\text { Domestic, detergent, } \\
\text { cosmetics, textile, } \\
\text { paper, agricultural } \\
\text { sectors, and petroleum } \\
\text { products }\end{array}$ & $\begin{array}{l}\text { Highly hydrophobic and } \\
\text { impressive adsorptive } \\
\text { capacity on solid } \\
\text { particles and } \\
\text { sediments. Exposure } \\
\text { to aquatic organisms }\end{array}$ & $\begin{array}{l}\text { AEOS has } \\
\text { excellent } \\
\text { biodegradabil- } \\
\text { ity, extensive } \\
\text { use }\end{array}$ \\
\hline
\end{tabular}

Table 2 Summary of the surfactant analysis methods

\begin{tabular}{|c|c|c|c|}
\hline Techniques & Uses/conditions & Advantages & Comment \\
\hline Spectrophotometry & $\begin{array}{l}\text { This method operates } \\
\text { based on complex } \\
\text { ion formation }\end{array}$ & $\begin{array}{l}\text { Economical, safe handling, and } \\
\text { ease of sample preparation }\end{array}$ & $\begin{array}{l}\text { It uses toxic solvents and possesses } \\
\text { low selectivity }\end{array}$ \\
\hline Potentiometry & $\begin{array}{l}\text { Operate based on the } \\
\text { variation of } \\
\text { electromotive force } \\
\text { (cell) }\end{array}$ & $\begin{array}{l}\text { Ease of operation and high } \\
\text { efficiency }\end{array}$ & $\begin{array}{l}\text { Difficult data reproducibility and } \\
\text { stability issues limit this } \\
\text { technique }\end{array}$ \\
\hline ATR-FTIR & $\begin{array}{l}\text { Uses spectrum } \\
\text { absorbance in the } \\
\text { infrared region to } \\
\text { analyse surfactants }\end{array}$ & $\begin{array}{l}\text { Useful for trace amount } \\
\text { detection, fast and high } \\
\text { sample throughput }\end{array}$ & $\begin{array}{l}\text { ATR-FTIR is an expensive } \\
\text { instrument and } \\
\text { transmission mode requires a lot } \\
\text { of time to prepare pellets and } \\
\text { grind } \mathrm{KBr}\end{array}$ \\
\hline Titrimetry & $\begin{array}{l}\text { Work on the principle } \\
\text { of off-line quantifi- } \\
\text { cation of the target } \\
\text { analytes }\end{array}$ & $\begin{array}{l}\text { Ease of operation and does not } \\
\text { require advanced analytical } \\
\text { instruments }\end{array}$ & $\begin{array}{l}\text { It applies to the specific analyte and } \\
\text { coloured matrix }\end{array}$ \\
\hline GC/MS & $\begin{array}{l}\text { Operate at ambient } \\
\text { conditions for the } \\
\text { analysis of volatile } \\
\text { compounds }\end{array}$ & $\begin{array}{l}\text { High resolution, fast method, } \\
\text { and high recovery of } \\
\text { analytes. Identification of } \\
\text { fragments }\end{array}$ & $\begin{array}{l}\text { Limited to low volatile oligomers } \\
\text { and requires derivatization }\end{array}$ \\
\hline SFC (HPLC/MS) & $\begin{array}{l}\text { It involves the use of } \\
\text { stationary and } \\
\text { mobile phases to } \\
\text { determine } \\
\text { surfactants }\end{array}$ & $\begin{array}{l}\text { High selectivity, } \\
\text { environmentally friendly, } \\
\text { shorter analysis time, } \\
\text { repeatability, robustness, } \\
\text { non-toxic, and } \\
\text { non-flammability }\end{array}$ & $\begin{array}{l}\text { Very sophisticated and possesses } \\
\text { high analytical capacity }\end{array}$ \\
\hline
\end{tabular}


component, the spectrophotometric technique could be sufficient. However, when the surfactant is a component of an environmental matrix, a precipitating (such as titrimetry) or separating (chromatography) technique would be required. Because of the capability to specifically identify surfactant types, chromatographic techniques (mainly HPLC-MS and GC/MS) are the most common methods usually adopted to analyse various surfactants (anionic, cationic, non-ionic, amphiprotic, and semi-polar surfactant groups). With these techniques, each homologue, ethoxyemers, or isomers are identified from surfactant blends in numerous environmental matrices. The following sub-sections give more discussions on the various analytical techniques employed to identify surfactants in an environmental sample.

\section{Spectrophotometric analysis}

Spectrophotometric analysis of surfactant ensures a fast and easy method of surfactant analysis. The most common spectroscopic technique is the $\mathrm{UV}-\mathrm{V}$ is. $\mathrm{UV}-\mathrm{V}$ is spectrophotometer uses an electronic transmission band in a UV-visible region. This technique focuses on developing surfactants with targeted ion-pair reagents and their extraction into acceptable hydrophobic solvents (Kurrey et al. 2019). For example, this technique was applied to evaluate linear alkylbenzene sulfonate concentration based on ionic pair surfactant methylene blue formation (Hu et al. 2019). In the analysis of surfactants using UV-Vis, different compounds show different bands during the spectrometry experiment. According to Silva et al. (da Silva et al. 2015), the wavelength range of nonylphenol ethoxylate ranges from 260 to $290 \mathrm{~nm}$ (Fig. 3) during the decontamination of $\mathrm{NP}_{4} \mathrm{EO}$ in wastewater. However, this technique generates a lot of toxic wastes. Another major drawback is that chromophores must be found in the samples

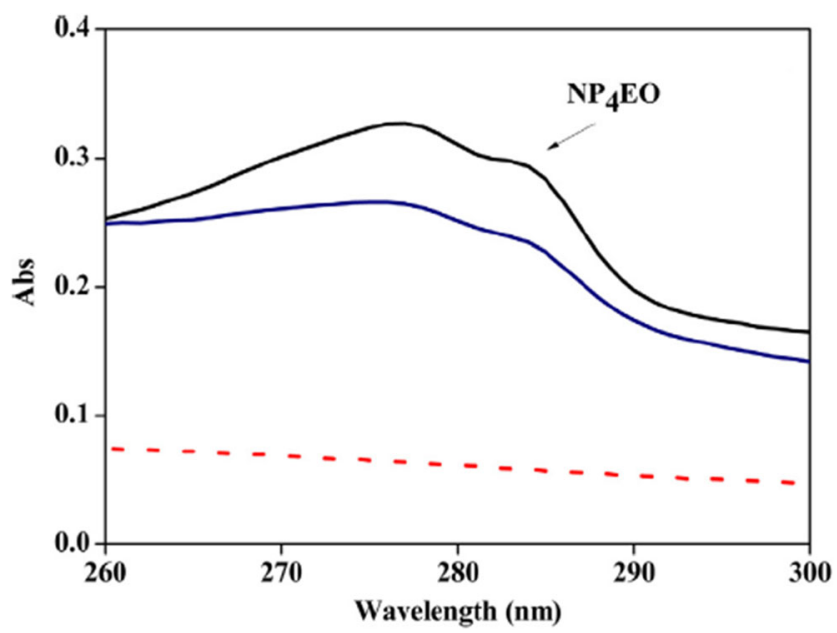

Fig. 3 UV-Vis spectrum from the analysis of NP4EO in wastewater (da Silva et al. 2015)
(Robards et al. 1999; Morales-Muñoz et al. 2004). Also, this technique is not suitable for determining the surfactant group present as a component of a large matrix.

\section{Potentiometric analysis}

The potentiometric titration technique can analyse the total ionic and non-ionic surfactant components. This technique works based on the change in the electromotive force cell after adding different titrants volume. Herein, the detection is ion-selective which is observed at the end-point of titration (Kurrey et al. 2019). Despite this advantage, this technique is not suitable for individual component analysis in a mixture of surfactants. Besides, the difficulty associated with signal stability and data reproducibility limits the use of this technique.

Ion-selective potentiometric has been used for the analysis of cationic and non-ionic surfactants. The analysis works based on ionophores using ion-selective electrodes (SakBosnar et al. 2015). Nevertheless, according to Masadome and Imato, this technique has also been used to analyse sodium lauryl ether sulphate (SLES), an anionic surfactant (Masadome et al. 1999). Therefore, the potentiometric analysis base on ion-selective electrodes applies to large varieties of environmental matrices. This technique offers several advantages: reliability, reduced monitoring time, not destructive to analytes, higher sensitivity, and less expensive compared to spectrometric and chromatographic analytical techniques. Recent advances in the ion-selective potentiometric analysis are based on modification with carbon nanotubes and nanomaterials. Special review articles have been devoted to these developments in the last 2 decades (Dimeski et al. 2010; Jozanović et al. 2019; Menger et al. 2021; Ostos et al. 2021).

\section{Attenuated total reflectance Fourier transform infrared spectrometry}

Attenuated total reflectance Fourier transform infrared spectrometry (ATR-FTIR) is an essential technique in analysing complex multicomponent mixtures (Kargosha et al. 2008; Mansourian et al. 2019). This technique works on the principle of spectrum absorbance in an infrared region. This technique can be applied to determine the different surfactants in a mixture simultaneously (Carolei and Gutz 2005). Besides, this technique is reliable and stable and has a short time on-stream for the analysis. One major drawback is the lack of suitability to analyse a trace compound (Carolei and Gutz 2005).

Moreover, the instrumental cost is another pitfall. Further, water used as a solvent in this technique has a sizeable interference in the absorption range. A recent development in this analytical technique is the use of paper substrate during the analysis. Kurrey et al. (2020) proposed a paper-based KBr to replace the traditional $\mathrm{KBr}$ pellet as a sample holder. 


\section{Titrimetry}

Titrimetry is commonly employed in the analysis of some non-ionic and cationic surfactants. This approach utilizes the principle of off-line quantification of targeted mixtures with the type of surfactant (Beneito-Cambra et al. 2013). Details working principles are outlined in the review of Kurrey et al. (2019). One advantage of this analysis is that sample pretreatment is not required. On the contrary, this technique is limited by the narrow range of sample analysis and complex operation mode (Beneito-Cambra et al. 2013).

\section{Gas chromatography}

In coping with the challenges of traditional analytical techniques, gas chromatography has important advantages of separating complex matrices and analysing low molecular mass metabolites. On the other hand, the technique requires the compounds' derivatization and their metabolites (Robards et al. 1999). Moreover, the detection limit is influenced by the choice of detector employed (Patil and Jain 2021). In recent times, common detectors used to analyse target compounds include chemical ionization, flame ionization detector, electron impact, tandem mass spectrometry, and single quadrupole (Petrović and Barceló 2000; Clara et al. 2007). Gas chromatography-mass spectrometry has been successfully used to separate and analyse linear alkylbenzene sulfonate in different samples. GC analysis is a suitable analytical technique for different types of surfactants due to implementing the hybrid of a capillary column and flame ionization detector. However, the use of GC for the analysis of cationic surfactants has not been fully outlined in the open literature.

\section{High-performance liquid chromatography (HPLC)}

High-performance liquid chromatography (HPLC) is currently the most utilized technique for analysing surfactants in an environmental matrix. For the most part, it is used for the analysis of low and high molecular weight analytes. There is no need for derivatization in this analysis. Furthermore, this technique is helpful for non-volatile analytes and different surfactants group and biodegraded products. Interestingly, the use of HPLC overcomes much of the challenges posed by the earlier discussed techniques. However, the major setback in the application of HPLC revolves around the need to isolate and extract analytes before the analysis. Principally, the HPLC utilizes different solid-liquid partitioning systems to identify the target analytes. Like GC-MS, HPLC has a low limit of detection (LOD); it could detect as low as $0.0002 \mathrm{mg} /$ L (Liu et al. 2006). Moreover, this technique has been used to simultaneously determine and quantify different surfactants classes with high accuracy (Im et al. 2008). Most HPLC detectors (such as MS, MS-MS, UV, conductivity, evaporative light scattering, refractive index, FLD, and fluorescence) have been applied to identify different surfactants.

\section{Supercritical fluid chromatography (SFC)}

Recent advances in the analysis of surfactants include the use of supercritical fluid chromatography (SFC) to separate and identify surfactants (Ma et al. 2019). A fluid at a critical point (i.e. temperature and pressure) where there is no distinct liquid or gas is said to be a supercritical fluid (SF). SFs have similar density with liquid and similar viscosity with gas phase, thereby combining the good advantages of both fluid phases. As a result, SFC shares the strong points of both GC and HPLC. Although HPLC has better selectivity, SFC is superior in efficiency and sensitivity. Also, the use of SFC can circumvent the inherent toxicity and flammability associated with liquid chromatography. Moreover, SFC is less expensive and more environmentally friendly and operates at a higher flow rate than liquid chromatography. $\mathrm{CO}_{2}$ is often used as the mobile phase because of its low cost, UV inertness, non-toxicity, good solvent properties, and low critical temperature $\left(31.1^{\circ} \mathrm{C}\right)$ and pressure $(72 \mathrm{bar})$ that are easy to attain. The selection of the stationary phase, on the other hand, is determined using the solvato-chromic model ( $\mathrm{Lv}$ et al. 2014).

There is a wide range of detectors that can be used with SFC. Standard detectors commonly used include flame ionization detector, evaporative light scattering detection, Fourier transforms infrared spectroscopy, corona-charged aerosol detection, and ultraviolet-visible detection (Shah et al. 2015; Tang et al. 2020). Tang et al. (Tang et al. 2020) used quadrupole time-of-flight mass spectrometry coupled with SFC to identify different pentaerythritol fatty acid esters. The application of supercritical fluid chromatography marked a notable advance in the study of pentaerythritol fatty acid esters. On the opposite side, SFC relies on a pure chemical of high purity, which is expensive to afford for most small laboratories.

\section{Biological techniques}

Some biological techniques are employed for the analysis of surfactants considering their health risks and toxicological impacts. For instance, ethoxylated alkylphenol, alkylphenol, and their biodegraded products cause endocrine disruption and teratogenic and estrogenic effects (Priac et al. 2017; Acir and Guenther 2018). The conventional chemical and electrochemical analytical techniques are time-consuming and required technical know-how and sophisticated instruments. However, analysis of food samples, animals, and many other environmental samples required techniques that are simple, quick, and reliable. Immunochemistry, molecular, and biosensors are among the biological techniques commonly used for the analysis of surfactants. The enzyme-linked immunosorbent assay (ELISA) is a modern immunochemistry 
technique that is highly sensitive and cost-effective, requires short-time analysis and fewer technical skills, and provides reliable analytical results. For example, the average inhibitory concentration $\left(\mathrm{IC}_{50}\right)$ of octylphenol was quantified with ELISA by incorporating a linear carboxylated analogue of 4nonylphenol (hapten) into carrier protein (as either monoclonal or polyclonal antibody) ( $\mathrm{Li}$ et al. 2014). The $\mathrm{IC}_{50}$ value of the synthesized hapten with polyclonal and monoclonal was $51 \mathrm{ng} / \mathrm{mL}$ and $76 \mathrm{ng} / \mathrm{mL}$. Another less sensitive biological analytical technique such as capillary electrophoresis has been previously reported (Acir and Guenther 2018). Moreover, the polymerase or gyrase chain reaction technique is the most advanced biological technique usually deployed for the detection of surfactants particularly alkylphenol, ethoxylated alkylphenol in animals. PCR is a thermocycling process used for the amplification of interested DNA sequences. The polymerase chain reaction technique is a molecular technique that is very rapid, highly sensitive, reliable, and accurate in detecting the gene sequences of interest. This method relies solely on the effects of surfactants (mostly endocrine disruptors) on the gene expression of the important neuroendocrine system. Due to the effect of the nonylphenol on the aromatase transcript of Atlantic salmon, quantitative PCR has successfully been used to quantify the gene expression of cytochrome P450N (Cyp 19). Kortner et al. (2009) carefully discussed how immunohistology and immunoblotting and titrated water-release assays were used to evaluate aromatase protein immunoreactivity and aromatase activity in Atlantic salmon's brain due to the presence of nonylphenol (Table 3).

\section{Assessment of surfactants in environmental matrix}

The excessive discharge of surfactants in the environment endangers human health and ecological safety. Therefore, several assessment techniques are employed to separate, identify, and quantify the surfactants in an environmental matrix. This section focuses on various assessment techniques through which different surfactants in environmental samples can be quantified. The integrity and efficacy of assessment techniques depend primarily on the level of environmental contamination and the remediation technologies' efficiency. The assessment techniques include spectrophotometric, potentiometric, voltammetric, and chromatographic methods. The operational principles, weaknesses, and the strengths of each assessment method are discussed in this section.

\section{Titrimetric analysis}

The titrimetric analysis is one method used to determine the critical micelles concentration of cationic, anionic, and nonionic surfactants without pre-treatment. The pre-treatment procedure includes the mixture of extraction and or preconcentration of the analytes in the samples (van Os et al. 1993; Wu et al. 2020). Traditionally, the conductivity, surface tension, and intensity of fluorescence are indicators to determine the critical micelles concentration of surfactants (Scholz et al. 2018; Ghosh et al. 2020). However, this method is tedious and time-consuming and requires a large sample size (Harkins and Introduction 1947; Cui et al. 2014). Therefore, the adoption of coloured or fluorescence ionic organic titrant was proposed to optimize this method and eliminate the traditional approach's identified problems. This new approach is rapid, simple, and cost-effective. However, the approach is limited to cationic and anionic surfactants (Harkins and Introduction 1947; Cui et al. 2014). Recently, C6-unsubstituted tetra pyrimidine (THP-Ti) was proven as an excellent indicator to determine the CMC of a wide range of surfactants (Wu et al. 2020). Titrimetry were employed to assess dialkyl dimethyl ammonium and ethoxylated surfactants, sodium dodecyl sulfonates, sodium dodecyl dimethyl benzyl ammonium chloride, and dodecyl dimethyl betaine in environmental samples (Borrego et al. 2000; Beneito-Cambra et al. 2013; Wu et al. 2020). Fig. 4 shows the determination of sodium dodecyl sulfonates (SDS) content using titrimetry analysis.

\section{Bismuth active substance method and other related modified methods}

Bismuth active substance method or other modified methods are employed to measure fatty alcohol and alkylphenol ethoxylated surfactants. The usual modified methods are the Wick bold method and the use of modified Dragendorff reagent. These methods depend mainly on potentiometric, spectrophotometric, and atomic absorption spectrophotometric principles to determine surfactants' concentration in environmental analytes. The potentiometric method depends on the changes in the environmental medium's electrical properties due to surfactants' presence (Lara-Martín et al. 2012). The spectrophotometric and the potentiometric approaches involve the determination of absorbance of the precipitate of bismuth-EDTA complex, yellow ternary $\mathrm{Pb}$ (II)-[meso-tetra-(3,5-dibromo-4-hydrooxyphenyl)-porphyrin]-APEO complex, ferric thiocyanate complex, iron(III) thiocyanate complex, pseudo-cation complexes of sodium or potassium ethoxylated compounds, and non-precipitate excess of molybdenum (Beneito-Cambra et al. 2013; Olkowska et al. 2013). This assessment method is simple, rapid, and reasonably sensitive and selective for specific surfactants in environmental matrices (Jurado et al. 2002; Lara-Martín et al. 2012; BeneitoCambra et al. 2013). However, the spectrophotometric method can generate huge toxic wastes and is incapable of measuring the total surfactants' concentration (Yamamoto et al. 2002; Zhu et al. 2003). Also, there are problems with signal instability and reproducibility of the potentiometric method 
Table 3 Analytical techniques for various surfactants in environmental samples

\begin{tabular}{|c|c|c|c|}
\hline Technique & Surfactant & Detectors & References \\
\hline $\begin{array}{l}\text { Potentiometry } \\
\text { titration }\end{array}$ & $\begin{array}{l}\text { Methylene blue active substance } \\
\text { (MBAS) and disulphine blue ac- } \\
\text { tive substance (DBAS) }\end{array}$ & $\mathrm{UV}-\mathrm{V}$ is & Roslan et al. (2010) \\
\hline Titrimetry & $\begin{array}{l}\text { Disodium cocoyl } \\
\text { monoethanolamide sulfosuccinate } \\
\text { (DMSS) }\end{array}$ & & Lv et al. (2014) \\
\hline ATR-FTIR & Sodium lauryl ether sulphate (SLES) & & $\begin{array}{l}\text { Carolei and Gutz } \\
\text { (2005); } \\
\text { Mansourian et al. } \\
\text { (2019) }\end{array}$ \\
\hline ATR-FTIR & $\begin{array}{l}\text { Coconut diethanol amide (CDEA) } \\
\text { and linear alkylbenzene sulfonates } \\
\text { (LABS) }\end{array}$ & & $\begin{array}{l}\text { Kargosha et al. } \\
\quad(2008)\end{array}$ \\
\hline ATR-FTIR & $\begin{array}{l}\text { Cocamidopropyl betaine (CAPB) } \\
\text { and alkylpolyglucoside (APG) }\end{array}$ & & $\begin{array}{l}\text { Carolei and Gutz } \\
\text { (2005) }\end{array}$ \\
\hline Spectroscopy & $\begin{array}{l}\text { Alkylbenzene sulfonates, } \\
\text { hydroxyl-oxo-amides }\end{array}$ & & $\begin{array}{l}\text { Cochran et al. } \\
\text { (2016) }\end{array}$ \\
\hline $\begin{array}{l}\text { Gas } \\
\text { chromatography }\end{array}$ & $\begin{array}{l}\text { Linear alkylbenzene sulfonates } \\
\text { (LAS) and lauryl alcohol } \\
\text { ethoxylates (LAEs) }\end{array}$ & MS & $\begin{array}{l}\text { Motteran et al. } \\
\text { (2019) }\end{array}$ \\
\hline $\begin{array}{l}\text { Liquid } \\
\text { chromatography } \\
\text { (LC) }\end{array}$ & Polyfluorooctane sulfonate (PFOS) & UV & Kim et al. (2018) \\
\hline $\begin{array}{l}\text { High-performance } \\
\text { LC }\end{array}$ & $\begin{array}{l}\text { Linear alkyl benzenesulfonates } \\
\text { (LAS) }\end{array}$ & ELSD & Liu et al. (2006) \\
\hline $\begin{array}{l}\text { Supercritical fluid } \\
\text { chromatography } \\
\text { (SFC) }\end{array}$ & $\begin{array}{l}\text { Octylphenol ethoxylates (OPEOs) } \\
\text { and lauryl alcohol ethoxylates } \\
\text { (LAEs) }\end{array}$ & MS & Ma et al. (2019) \\
\hline $\begin{array}{l}\text { ELISA (biological } \\
\text { technique) }\end{array}$ & Octylphenol (hapten) & $\begin{array}{l}\text { Monoclonal/polyclonal } \\
\text { antibody }\end{array}$ & Li et al. (2014) \\
\hline
\end{tabular}

(Ali et al. 2018). This method's success depends significantly on the quantities of targeted surfactant in the environmental samples, pre-treatment efficiency, and accurate prediction of absorbance wavelength range (Beneito-Cambra et al. 2013).

\section{Fourier transform infrared spectrometry (FTIR)}

Fourier transform infrared spectrometry is a prominent method used in assessing non-ionic surfactants (Gartshore et al. 2000; Carolei and Gutz 2005). Here, the non-ionic surfactants must be extracted and concentrated through the salting-out procedure (Andrew 1993). The process is easy, fast, and sensitive for a particular class of surfactant (Beneito-Cambra et al. 2013). However, this method is not suitable for the evaluation of the absolute value of non-ionic surfactants. Soap formation can interfere with the efficiency of this method. Linear alkyl benzyl sulfonate and sodium lauryl ether sulphate were simultaneously quantified with ATR-FTIR coupled with PLS regression (Carolei and Gutz 2005; Kargosha et al. 2008).

\section{Voltammetric technique}

Voltammetric techniques are among electroanalytical procedures used for quantitative analysis of environmental samples.
Notably, these techniques are less significant than chromatographic, electrophoretic, and spectrophotometric because they fail to assess mixtures of different surfactants in environmental samples (Sander and Henze 1997; Beneito-Cambra et al. 2013). However, voltammetry offers a superior specific analysis to surfactants in environmental samples. The techniques are based on the principles of ionic conductivity of the analytes and variation in the analytes' transport charges. So, the voltammetric techniques are used to measure conduction charge transport of the electrolyte interface (i.e. measuring the electrode potential of the analytes) (Scholz 2015). Due to micelles' potential to adsorbed electroactive species, the diffusion coefficient of the CMC of surfactants is quantified with voltammetric techniques. In perspective, voltammetric techniques are employed to precisely quantify non-ionic surfactants in surface water, sewage, WWTPs effluents, etc. (Szymanski et al. 1996; Nesměrák and Němcová 2006). Previously, 1-30 ethylene oxide units of the AEs and APEs surfactants were measured on the surface of the working electrode, i.e. hanging mercury drop electrode (HDME) (Gerlache et al. 1996; Cvrković-Karloci et al. 2011). The measurement was made possible because monitoring substances (EOs) were adsorbed on the surface of HDME during pre-concentration. 


\section{Chromatographic technique}

The chromatographic method is the most advanced assessment method for surfactants in an environmental sample. The method is sensitive and specific and possesses an excellent capacity to separate, identify, and quantify each surfactant in the environmental matrix within the shortest possible time. The method is majorly classified into gas chromatography and liquid chromatography. Several studies have shown that gas chromatography and highperformance liquid chromatography coupled with postcolumn, conductive, or UV-detectors can assess the ethylene oxide units in the various surfactants (Gerlache et al. 1996; Lobachev and Kolotvin 2006).

\section{Gas chromatography method}

Gas chromatography (GC) can directly analyse low molecular mass and non-ionic surfactants (such as NPs and short chains NPEOs) without derivatization (Bartolomé et al. 2005; Nagarnaik et al. 2010). GC cannot, however, assess low volatile ethoxylated oligomers. Therefore, the GC can only assess surfactants that were derivatized with specific agents to eliminate volatilization and separation challenges (Bennie et al. 1997; Bengoechea and Cantarero 2009; Jiménez-díaz et al. 2010). However, capillary GC mass spectrometry (MS) has been used to assess low volatile ethoxylated compounds (Beneito-Cambra et al. 2013). It has been established that the method tends to degrade ethylene oxide composition of the surfactants (Beneito-Cambra et al. 2013). The GC has an excellent capacity to separate homologues and isomers of different surfactants after derivatization. Distinctively, non-polar capillary column GC can effectively analyse both anionic and non-ionic surfactants (Bartolomé et al. 2005; Luo et al. 2010). Some detectors are coupled with the GC to assess surfactants, such as flame ionization, chemical ionization, mass spectrometry, and quadrupole mass spectrometry. However, chemical ionization showed better quantification performance (Alzaga et al. 2003; Pan and Tsai 2008; Hibberd et al. 2009). Fig. 4 shows the application of GC columns for the analysis of alkyldimethylamines, a non-ionic surfactant(Fig. 5).

\section{Liquid chromatography}

Liquid chromatography (LC) is employed to assess non-volatile, low molecular weight surfactants such as bio-surfactants and biodegraded surfactants. Unlike GC, liquid chromatography analyses environmental samples without derivatization. The LC employed for surfactants usually adopts a reversephase column (León et al. 2000; Merino et al. 2004; LaraMartín et al. 2006; Rico-Rico et al. 2009; Bassarab et al.

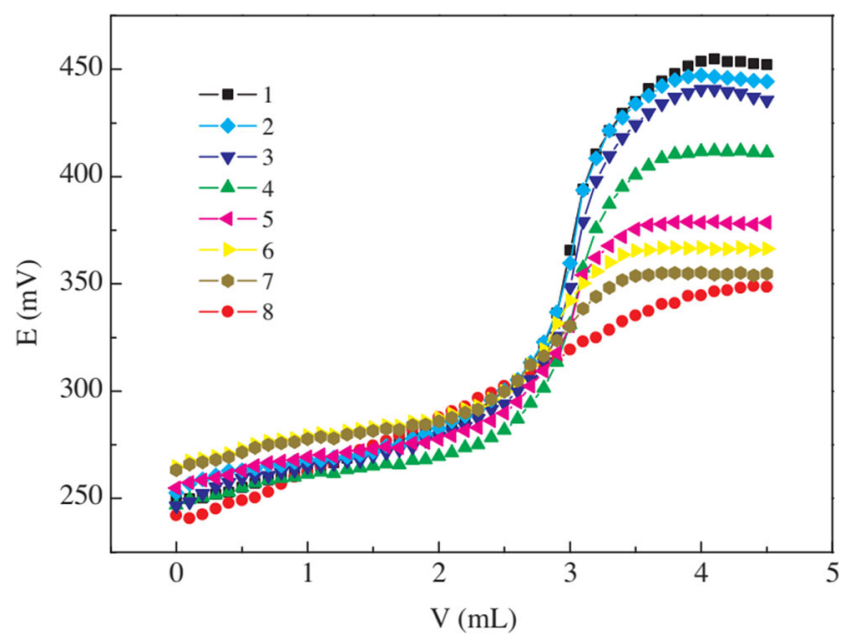

Fig. 4 Titrimetric analysis of SDS (reproduced from (Wang et al. 2012))

2011). Mass spectrometry (MS), ion-trap MS $\left(M^{\mathrm{n}}{ }^{\mathrm{n}}\right)$, triple quadrupole MS (MS-MS), time of flight MS (ToF-MS), and quadrupole ToF MS (Q-ToF-MS) are typical detector used in the analysis of surfactants (Lunar et al. 2004; Lara-Martín et al. 2012). The method is used to quantify NP and octylphenol ethoxylates in the environmental samples (Loyo-Rosales et al. 2003).

HPLC is an advanced type of LC involving the use of high pressure in the liquid mobile phase. High-performance liquid chromatography with UV or fluorescence detectors is used to analyse LAS and NPEOs in environmental samples (Villar et al. 2007; Cantarero et al. 2011). The ultra-power LC (UPLC) coupled with Q-ToF-MS is the most advanced approach to effectively analyse trace quantities of analytes within the shortest recorded time (Lara-Martín et al. 2010, 2012).

\section{Remediation of surfactants}

The presence of surfactants in aquatic and terrestrial environments poses an adverse effect on microorganisms, plants, animals, and humans. The immense usage of surfactants, their health hazards, and strict regulatory policies on their allowable limit call for their control in the environment. This allowable limit has been a subject of debate among several researchers. Therefore, several remediation approaches have been recommended for the clean-up of surfactants in the environment. In past decades, bioremediation is often employed in the removal of surfactants from the environmental matrix. Recently, the available remediation methods encompass the physical, chemical, biological, and membrane techniques (Siyal et al. 2020). The biological and physical remediation approaches, including gravity settling, cannot wholly remove both anionic surfactants and organic matters when the pollutant concentration is high (Sriwiriyarat et al. 2017). The appropriate remediation method is influenced by many factors such as treatment 
Fig. 5 Extracted EI ion chromatogram of alkyldimethylamines (ADMAs) and its corresponding mass spectra (reproduced from Tsai and Ding 2004)

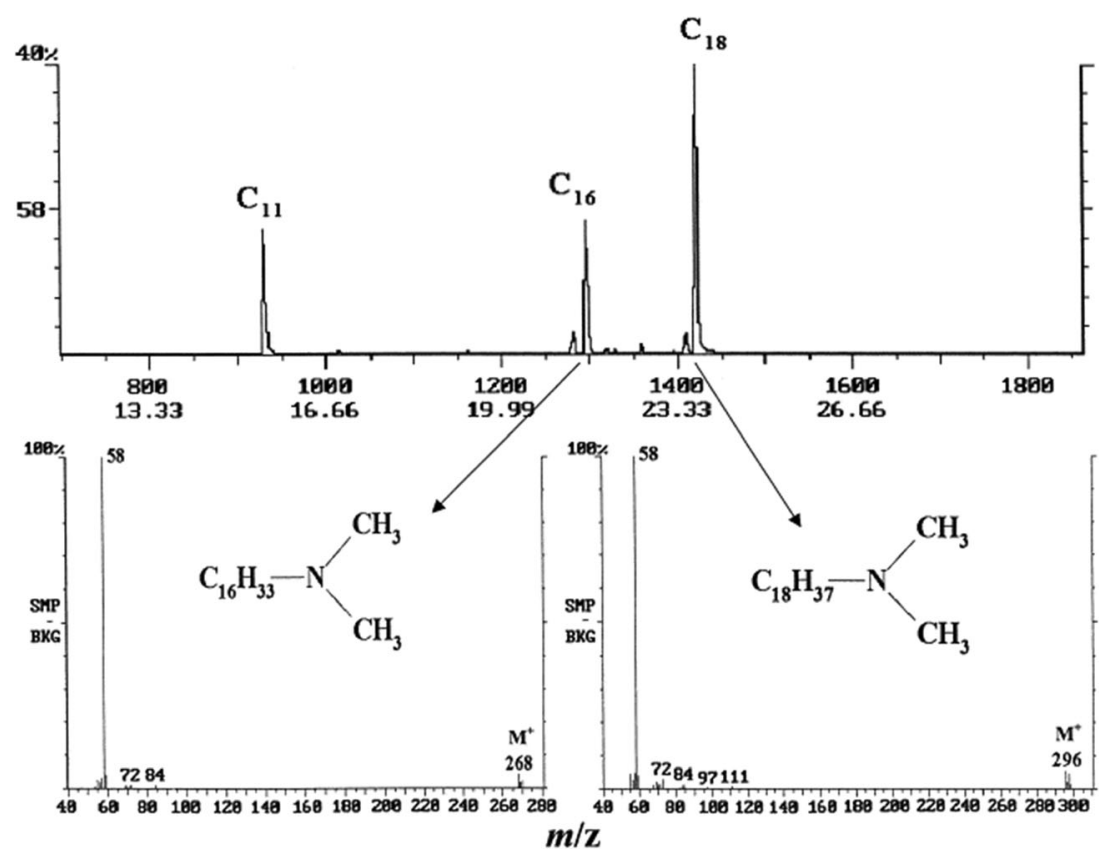

efficiency, operation time, effluent and influent characteristics, and power usage. A detailed overview of the remediation methods is provided in the remaining part of this section.

\section{Physical methods}

Adsorption is the most common physical method due to its effectiveness in surfactant removal. Various materials are currently utilized as adsorbents, such as activated carbon, nanomaterials, zeolites, clay, and resin. However, the use of these adsorbents is limited due to their costs. By far, activated carbon is the best material used as an adsorbent (Valizadeh et al. 2016; Siyal et al. 2020). On the other hand, its development is often an arduous task. In recent times, a lot of attention is being focused on developing environmentally safe, cheap, and highly efficient adsorbents as alternatives to activated carbon. Siyal et al. (Siyal et al. 2020) summarized recent advances in adsorbent development. One emerging approach is developing green adsorbents from waste materials to mitigate the challenges in the application of adsorption for surfactant removal from wastewater. Hossain et al. (Hossain et al. 2020) outlined several diverse materials used as waste adsorbents. It was hypothesized that the application of this type of materials enhances waste management and contributes to economic growth. These materials are either used as an as-received unmodified or modified adsorbent or combined with other techniques for surfactant remediation (Gupta et al. 2009). Despite the potential benefits involved in the use of green adsorbents, more research should be directed on the socio-economic and techno-economic analyses of the concept (Gupta et al. 2009).

Another emerging methodology for surfactant removal is the use of nanomaterials ( $\mathrm{Lu}$ and Astruc 2020; Scaria et al.
2020). However, this approach's major impediments are sustaining the synergy between the nanomaterial's physicochemical properties and the surfactants' composition. These two phenomena influence maximal removal efficiency. Moreover, the mechanism involved in this approach plays a vital role in the efficiency of this method. The relationship between different surfactants composition and nanomaterials' physicochemical properties on the surfactant removal efficiency has been extensively reviewed. For instance, Gao et al. (Gao et al. 2020) used various carbon nanotubes to compare the remediation of three cationic surfactants, namely, hexadecyltrimethylammonium bromide (CTAB), tetradecyl dimethyl benzyl ammonium chloride (TDBAC), and dodecyl dimethyl benzyl ammonium chloride (DDBAC). The authors used pure functionalized multiwalled carbon nanotubes (MWCNTs) and $\mathrm{OH}^{-} / \mathrm{COOH}^{-}$modified CNTs. It was shown that porosity and large surface area increase the efficiency of any CNTs. Also, there is an optimum amount of CNTs required to achieve maximum efficiency. The outer diameter and functional groups of carbon nanotubes determine its removal performance. For instance, smaller outer diameter CNTs with no hydrophilic groups perform more than large CNTs comprising hydrophilic functions in cationic removal (Gao et al. 2020). The multiwalled carbon nanotubes have been found to efficiently remove both non-ionic and anionic surfactants but hardly removed cationic surfactants (Bai et al. 2010; Yang et al. 2010; Gao et al. 2020). However, the cationic surfactants' removal capacity of carbon nanomaterials largely depends on nanomaterials' physicochemical properties and the cationic surfactant's composition (Gao et al. 2020). 
Foam fractionation is a promising method to remove surfactants from wastewater. In practice, this method produces foam by injecting air into a fractionation column consisting of water contaminated with surfactants. Thus, surfactants are separated from the polluted water based on their mass concentration differences. Consequently, this forms a surfactant-rich foam layer at the top of the column and the aqueous-rich layer at the column's bottom (Figs. 6 and 7). Advances in the remediation of surfactants from wastewater via this process are based on nanoparticle use via stabilization of foam. For example, Hu et al. (2019) used silicon nanoparticles (SNP) as an efficient foam stabilizer to improve LAS adsorption and foam stability. Formability and foam stability are two crucial factors that influence foam property. Activated SNP adversely affected formability due to the rise in viscosity. A high viscosity will hinder air entrainment and reduce bubble formation $(\mathrm{Hu}$ et al. 2019). Consequently, this will reduce surfactant removal efficiency.

One promising technology for recovering and removing surfactants from wastewater is low-cost and straightforward foam fractionation (Burghoff 2012). The single or multi-stage foam fractionation column can operate either batch-wise or continuous manner (Srinet et al. 2017). Generally, air flow rate, attainment of critical micelle concentration, the volume of foam, sonication time, and power significantly influence foam fractionation (Srinet et al. 2017; Fei et al. 2018). Extensive studies have been reported on the effects of airflow rate, feed flow rate, time, foam height, and liquid height to remove anionic surfactants (e.g. sodium dodecyl sulphate) (Srinet et al. 2017). The high specific surface area and low interstitial liquid make foam a suitable medium for the adsorption of surfactants (Srinet et al. 2017). Despite the overwhelming works on foam fractionation, efforts towards its commercialization are yet to be concretized. Therefore, more findings are necessary to upscale and commercialize the foam fractionation.

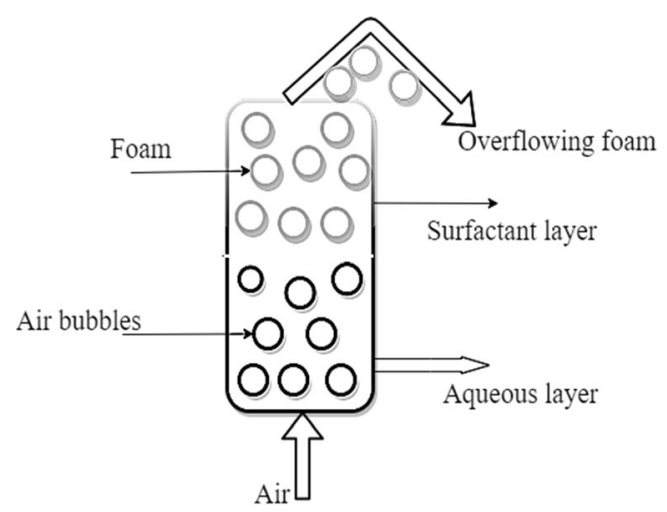

Fig. 6 Recovery of surfactant from foam fractionation

\section{Chemical methods}

The chemical remediation method provides an alternative to surfactant removal from waste systems. In practice, the application of chemical technologies in surfactant remediation leads to the generation of valuable products such as carbon dioxide, nitrogen, and water. There are different types of chemical treatment and their variants.

Coagulation is a very effective method. Naumczyk et al. (2017) clean-up highly polluted cosmetic wastewater using this technique based on iron and aluminium compounds. Aluminium-based coagulants perform best due to larger volumes and more extensive diversity obtained from sludgecontaining aluminium. Coagulation is also sometimes combined with other methods such as air flocculation and Fenton processes. Coagulation-flocculation is highly effective for the removal of pollutants in high concentrations. On the other hand, the Fenton process gave the lowest removal efficiency compared with other mentioned processes, according to the study. The choice of coagulants also affects the efficiency of the coagulation process. In most instances, the coagulants create another waste if not correctly discharged (Li et al. 2018a). Thus, more efforts are required to select coagulants that can selectively remove waste surfactant from water and can be recovered without polluting the influent.

The treatment of surfactants from water by advanced oxidation processes (AOPs) has been proven as a promising remediation method for recalcitrant surfactants (Khan et al. 2018; Brandão et al. 2019; Zhou et al. 2019). Different techniques of AOPs currently employed for remediating surfactants are based on electrochemical, electro-Fenton, electroperoxide, and ultraviolet light irradiation. These processes present numerous advantages over the traditional chemical processes, such as freedom from the threat of carcinogenic chlorinated products and the release of pathogenic microorganisms (Esteban García et al. 2021).

Electrochemical advanced oxidation processes (EAOPs) are alternative remediation technologies for anionic surfactants. The process involves the application of electrochemistry techniques to degrade recalcitrant surfactants from wastewater. EAOPs are considered safe and ecologically benign. Its safety is due to the absence of adding chemicals to the process. This process uses the transfer of electrons between the electrodes by producing hydroxyl radicals to degrade polluting surfactants. Recently, Ganiyu et al. (2018a) compared three electrochemical processes (EO, EF, and EO$\mathrm{H}_{2} \mathrm{O}_{2}$ ) to remove anionic surfactants. The processes completely removed anionic surfactants present in the wastewater. In all three processes, an increase in applied current increases the COD (representing surfactant) removal efficiencies. It was reported that a higher electric current enhances speedy and large production of BDD (_OH). This in turn can readily oxidize the surfactant molecules in the system (Ganiyu et al. 


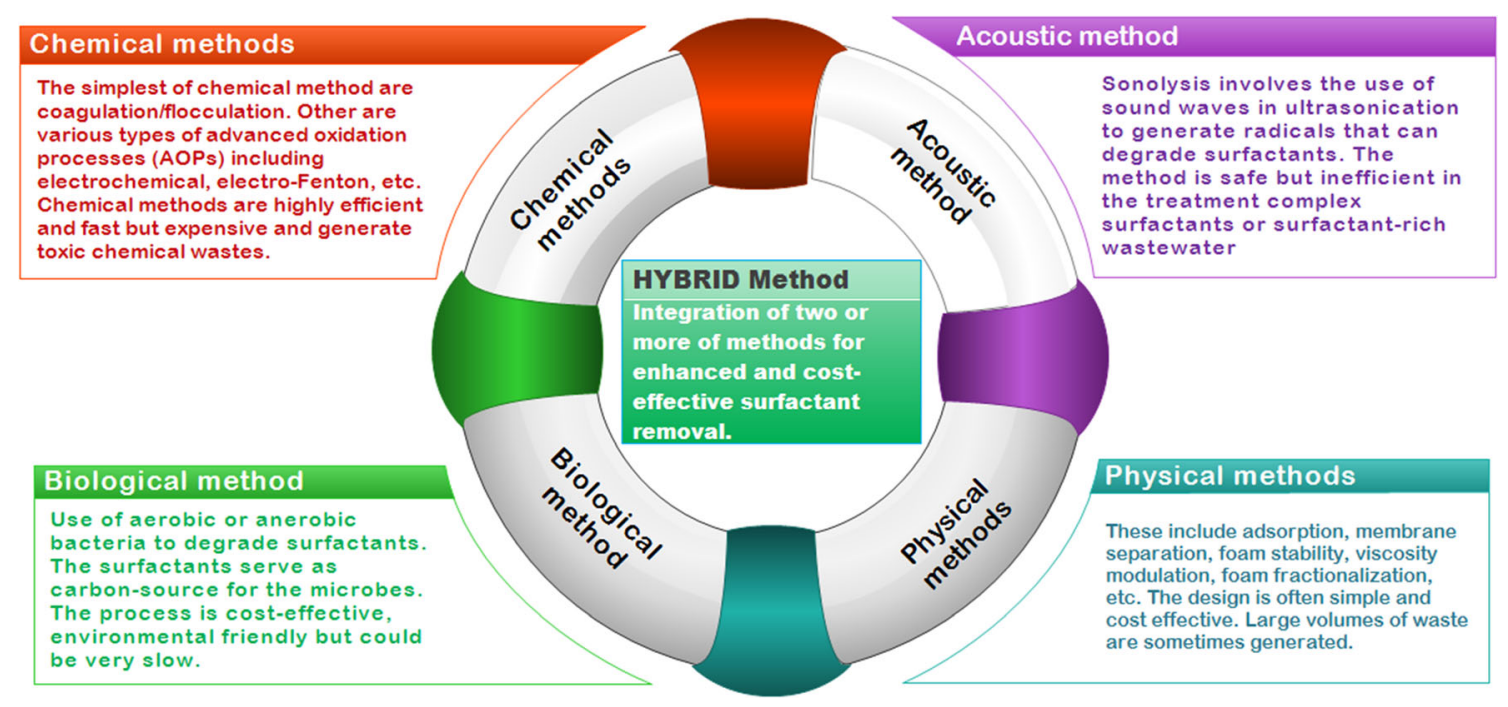

Fig. 7 A summary of surfactant removal methods

2018b; Martínez-Huitle and Panizza 2018). However, an increase in applied current density leads to unfavourable high energy consumptions. EF process tends to involve the lowest energy usage and current efficacy when the energy consumption of the three processes was compared. This is because, in the EF process, the two radicals produced from the process dissolve the organic matter.

Surfactants are also being removed using the anaerobic/ oxic process (Gao et al. 2017). In principle, the process comprises six compartments divided into two anoxic conditions and four oxic conditions. The anoxic treatment compartments play a critical role in surfactant removal. However, this process's removal efficiency is mainly influenced by seasonal changes in the region or country under consideration. Furthermore, an electron beam based on irradiation has also been employed in the removal of surfactants from wastewater treatment plants (Gupta et al. 2009; Ahmed et al. 2017; Lu and Astruc 2020). In this technique, the electron beam is irradiated in an aqueous solution at different doses to generate several species. Consequently, these generated species are used to degrade the aqueous pollutants. However, an explanation of the nature of the intermediates and products in this technique is still scanty in literature.

Sonoreactor for remediation of surfactants from wastewater presents numerous advantages: ease mode of operation, more benign to the environment, minimum chemical usage, free from sludge generation, and by-products. Also, the low cost of operation and maintenance make it an efficient advanced oxidation treatment process. In principle, this reactor operates on the principle of free radical generation (Mohajerani et al. 2010; Heidarinejad et al. 2018). Recently, Hadi et al. (Dehghani et al. 2019) applied a sonoreactor to degrade LAS from an aqueous solution. They found that LAS degradation increases with time. Contrastingly, an increase in initial LAS concentration decreases the LAS removal rate.
Increasing the acoustic power, on the other hand, leads to a higher degradation of LAS. This is because of the possible reaction in the cavitation of the sonoreactor. However, high acoustic power implied higher energy. Thus, a balance should be maintained between efficiency and energy cost.

\section{Biological methods}

The biological treatment method shares the advantages of lower operational costs and the use of green methods. This technique involves breaking down large molecular weight compounds into lower ones using microorganisms such as algae, fungi, and bacteria (Garcia-Rodríguez et al. 2014). Further details of the types, processes, and mechanisms can be found in the review of Ahmed et al. (Ahmed et al. 2017). The biological treatment techniques have some drawbacks: long operation time, inability towards toxic elements, and high surfactant concentrations. Consequently, these result in biomass death in the system (Collivignarelli et al. 2017; Palmer and Hatley 2018).

Advanced technologies are being developed with a hybrid of other processes to control some of the disadvantages of conventional biological treatment technologies. For instance, Collivignarelli et al. (2019) studied the removal of surfactants (ionic and non-ionic) with the aid of nanofiltration, thermophilic aerobic membranes reactors (TAMR), and sorption on carbons. The findings revealed that TAMR could withstand high-stress conditions and inhibit the high concentration of surfactants. Moreover, combining these three processes results in higher surfactant removal. However, cost-wise, $\mathrm{TAMR}+\mathrm{NF}$ represents the optimum process (Collivignarelli et al. 2019). Additionally, the thermophilic aerobic reactor's efficiency can be enhanced through the attachment of ultrafiltration as this will make the reactor hold the biomass and treat high concentrations of the target surfactants (Collivignarelli 
et al. 2015). A summary of general methods for the remediation of surfactants and their key merits and demerits is shown in Fig. 7, Table 4.

\section{Recommendations and conclusions}

\section{Recommendations and research gaps}

The analytical techniques used in surfactant characterization are rapidly growing. Among these techniques, supercritical fluid chromatography is a cost-effective, time-saving, and highly efficient technique for analysing a wide range of surfactants. Despite these overwhelming benefits, only a few studies have been reported for the use of this technique in assessing surfactants. Thus, SFC should be promoted in analysing different types of surfactants. Also, studies based on different detectors are necessary to cover all the types of environments and compounds. The use of SFC with HPLC coupled with MS detector could help easy identification and quantification of various surfactants.
Adsorbents derived from waste materials provide cheap and circular alternative treatments approaches for the recalcitrant surfactants in wastewater. Research attention should be devoted to the maximum recovery, regeneration, and safety of these materials. Future studies should integrate technoeconomic evaluation of these adsorbents for the potential commercialization.

Combining different chemical treatment technologies can efficiently remove various surfactants or enhance the efficiency of the current treatment practices. Towards this, coagulation may be combined with other techniques such as ozonation, UV irradiation, Fenton process, $\mathrm{H}_{2} \mathrm{O}_{2}$, and nanoparticles to contribute to the current practice of surfactants treatments.

Additionally, little information is available on the mechanism and kinetics of the electron beam oxidation process. Future research should investigate how the target surfactant is being degraded or the rate at which the process degrades surfactants. The policymakers and environmental regulatory agencies are strongly encouraged to draft guidelines and standards for the available classes of surfactants and their degraded products.
Table 4 Various surfactants treatment technologies and their performances

\begin{tabular}{|c|c|c|c|}
\hline Treatment method & $\begin{array}{l}\text { Surfactant (initial concentration } \\
500 \mathrm{ppm} \text { ) }\end{array}$ & $\begin{array}{l}\text { Removal } \\
\text { efficiency }(\%)\end{array}$ & $\mathbf{R f}$ \\
\hline Anaerobic/oxic process & Nonylphenol (NP) & 86 & Gao et al. (2017) \\
\hline Anaerobic/oxic process & $\begin{array}{l}\text { Nonylphenol mono-ethoxylate } \\
\text { (NP1EO) }\end{array}$ & 90 & Gao et al. (2017) \\
\hline Anaerobic/oxic process & Nonylphenol di-ethoxylate NP2EO) & 90 & Gao et al. (2017) \\
\hline Electron beam & Perfluorooctane sulfonate (PFOS) & 68.04 & Kim et al. (2018) \\
\hline Adsorption CNT & $\begin{array}{l}\text { Hexadecyl trimethyl ammonium } \\
\text { bromide (CTAB) }\end{array}$ & 50.36 & Gao et al. (2020) \\
\hline Adsorption SNP & $\begin{array}{l}\text { Linear alkylbenzene sulfonates } \\
\text { (LAS) }\end{array}$ & 90 & Hu et al. (2019) \\
\hline Electro-Fenton & Anionic surfactant & 100 & $\begin{array}{l}\text { Ganiyu et al. } \\
\text { (2018a) }\end{array}$ \\
\hline Coagulation & Anionic surfactant & 88.2 & $\begin{array}{l}\text { Naumczyk et al. } \\
\text { (2017) }\end{array}$ \\
\hline Coagulation & Anionic surfactant & 91.6 & $\begin{array}{l}\text { Naumczyk et al. } \\
\text { (2017) }\end{array}$ \\
\hline Coagulation-flocculation & Anionic surfactant & 87.3 & $\begin{array}{l}\text { Naumczyk et al. } \\
\text { (2017) }\end{array}$ \\
\hline Fenton process & Anionic surfactant & 72.7 & $\begin{array}{l}\text { Naumczyk et al. } \\
\text { (2017) }\end{array}$ \\
\hline Sonoreactor & $\begin{array}{l}\text { Linear alkylbenzene sulfonates } \\
\text { (LAS) }\end{array}$ & & $\begin{array}{l}\text { Dehghani et al. } \\
\text { (2019) }\end{array}$ \\
\hline $\mathrm{TAMR}+\mathrm{NF}+\mathrm{AC}$ & Non-ionic (TAS) & 95 & $\begin{array}{l}\text { Collivignarelli et al } \\
\text { (2019) }\end{array}$ \\
\hline $\mathrm{TAMR}+\mathrm{NF}+\mathrm{AC}$ & $\begin{array}{l}\text { Methylene blue active substance } \\
\text { (MBAS) }\end{array}$ & 76 & $\begin{array}{l}\text { Collivignarelli et al } \\
\text { (2019) }\end{array}$ \\
\hline Ozonation & $\begin{array}{l}\text { Anionic, cationic, and non-ionic sur- } \\
\text { factant }\end{array}$ & & $\begin{array}{l}\text { Delanghe et al. } \\
\text { (1991) }\end{array}$ \\
\hline
\end{tabular}




\section{Conclusions}

This comprehensive review has revealed the enormous ecotoxicity and human health implications of surfactants in the environment. The non-degradability, persistence, and toxicity of some surfactants and their transformed products have extreme environmental consequences. So, the balance and sustainability of natural ecosystems could be managed through assessment, practical analysis, and treatment of surfactants. Hence, several analytical, assessments, and remediation technologies are been employed to effectively identify, quantify, and clean up surfactants from environmental matrices. Based on the available literature, this work showed that chromatographic techniques particularly supercritical and quadrupole time of flight MS (Q-ToF-MS) fluid chromatography offer a better analysis of surfactants up to trace level concentrations in environmental matrices. Considering the strengths and challenges of various available remediation methods for the surfactants, foam fractionation, thermal aerobic membrane reactors, advanced adsorbent, and electrochemical advanced aerobic processes are effective methods. Future research should focus on the development of cheap adsorbents from wastes. However, extensive investigation on their recovery, regeneration, re-use, and techno-economic values should be considered. Also, it is pertinent to integrate or couple the current advanced remediation technologies to the existing wastewater treatment plants (WWTPs) for efficient removal of surfactants from the influents. Electron beam oxidation generates powerful radicals that can completely mineralize surfactants. However, its mechanisms, kinetics, and costs have not been adequately researched and documented. Lastly, this review is an attempt to foster proper understanding of practicable analysis and assessment as well as feasible remediation approaches to aid researchers, policymakers, and regulatory bodies in their bids to minimize environmental exposure to toxic surfactants.

Author contribution Suaibu O. Badmus conceptualized the idea, did literature survey, wrote the original draft, and participated in the revision.

Hussein K. Amusa was responsible for literature survey, writing original draft, and revision.

Tajudeen A. Oyehan was responsible for supervision, visualization, manuscript review, editing, and revision.

Tawfik A Saleh was responsible for supervision, funding, coordination, and revision.

Funding Authors would like to acknowledge the support and fund provided by King Fahd University of Petroleum \& Minerals (KFUPM) through Project No. DF191026 under the Deanship of Research.

Data availability Not applicable. All data are included in the paper.

\section{Declarations}

Ethical approval Not applicable

Consent to participate Not applicable because there is no human or animal subjects.

Consent for publication Not applicable

Competing interests The authors declare no competing interests.

\section{References}

Acir IH, Guenther K (2018) Endocrine-disrupting metabolites of alkylphenol ethoxylates - a critical review of analytical methods, environmental occurrences, toxicity, and regulation. Sci Total Environ 635:1530-1546. https://doi.org/10.1016/j.scitotenv.2018. 04.079

Ahmed MB, Zhou JL, Ngo HH, Guo W, Thomaidis NS, Xu J (2017) Progress in the biological and chemical treatment technologies for emerging contaminant removal from wastewater: A critical review. J Hazard Mater 323:274-298. https://doi.org/10.1016/j.jhazmat.2016. 04.045

Ali TA, Mohamed GG, El-Sonbati AZ et al (2018) A potentiometric sensor for determination of doxycycline hydrochloride in pharmaceutical preparation and biological fluids. Russ J Electrochem 54: 1081-1095. https://doi.org/10.1134/S1023193518120029

Alzaga R, Peña A, Ortiz L, Bayona JM (2003) Determination of linear alkylbenzensulfonates in aqueous matrices by ion-pair solid-phase microextraction-in-port derivatization-gas chromatography-mass spectrometry. J Chromatogr A 999:51-60. https://doi.org/10.1016/ S0021-9673(03)00493-X

Andrew BE (1993) Determination of non-ionic surfactants in waste water by direct extraction with Fourier transform infrared spectroscopic detection. Analyst 118:153-155. https://doi.org/10.1039/ AN9931800153

Argese E, Marcomini A, Bettiol C, Perin G, Miana P (1994) Submitochondrial particle response to linear alkylbenzene sulfonates, nonylphenol polyethoxylates and their biodegradation derivatives. Environ Toxicol Chem 13:737-742. https://doi.org/10.1002/ etc. 5620130507

Bai Y, Lin D, Wu F, Wang Z, Xing B (2010) Adsorption of Triton Xseries surfactants and its role in stabilizing multi-walled carbon nanotube suspensions. Chemosphere 79:362-367. https://doi.org/ 10.1016/j.chemosphere.2010.02.023

Bartolomé L, Cortazar E, Raposo JC, Usobiaga A, Zuloaga O, Etxebarria N, Fernández LA (2005) Simultaneous microwave-assisted extraction of polycyclic aromatic hydrocarbons, polychlorinated biphenyls, phthalate esters and nonylphenols in sediments. J Chromatogr A 1068:229-236. https://doi.org/10.1016/j.chroma. 2005.02 .003

Bassarab P, Williams D, Dean JR, Ludkin E, Perry JJ (2011) Determination of quaternary ammonium compounds in seawater samples by solid-phase extraction and liquid chromatographymass spectrometry. J Chromatogr A 1218:673-677. https://doi.org/ 10.1016/j.chroma.2010.11.088

Bautista-Toledo MI, Méndez-Díaz JD, Sánchez-Polo M, Rivera-Utrilla J, Ferro-García MA (2008) Adsorption of sodium dodecylbenzenesulfonate on activated carbons: effects of solution chemistry and presence of bacteria. J Colloid Interface Sci 317: 11-17. https://doi.org/10.1016/j.jcis.2007.09.039 
Bautista-Toledo MI, Rivera-Utrilla J, Méndez-Díaz JD, Sánchez-Polo M, Carrasco-Marín F (2014) Removal of the surfactant sodium dodecylbenzenesulfonate from water by processes based on adsorption/bioadsorption and biodegradation. J Colloid Interface Sci 418:113-119. https://doi.org/10.1016/j.jcis.2013.12.001

Beneito-Cambra M, Herrero-Martínez JM, Ramis-Ramos G (2013) Analytical methods for the characterization and determination of nonionic surfactants in cosmetics and environmental matrices. Anal Methods 5:341-354. https://doi.org/10.1039/c2ay25847a

Bengoechea C, Cantarero AS (2009) Analysis of linear alkylbenzene sulfonate in waste water and sludge by high performance liquid chromatography: an exercise of validation. J Surfactant Deterg 12: 21-29. https://doi.org/10.1007/s11743-008-1100-8

Bennie DT, Sullivan CA, Lee HB, Peart TE, Maguire RJ (1997) Occurrence of alkylphenols and alkylphenol mono- and diethoxylates in natural waters of the Laurentian Great Lakes basin and the upper St. Lawrence River. Sci Total Environ 193:263-275. https://doi.org/10.1016/S0048-9697(96)05386-7

Bering S, Mazur J, Tarnowski K, Dabkowska N, Janus M, Mozia S, Morawski AW (2018) Removal of organic pollutants and surfactants from laundry wastewater in membrane bioreactor (MBR). Desalin Water Treat 134:281-288. https://doi.org/10.5004/dwt. 2018.23207

Borghi CC, Fabbri M, Fiorini M, Mancini M, Ribani PL (2011) Magnetic removal of surfactants from wastewater using micrometric iron oxide powders. Sep Purif Technol 83:180-188. https://doi.org/10. 1016/j.seppur.2011.09.042

Borrego E, Sicilia D, Rubio S, Perez-Bendito D (2000) Simultaneous determination of cationic and nonionic surfactants in consumer products by use of mixed aggregate-based methodology. Analyst 125:1507-1512. https://doi.org/10.1039/b001788o

Brandão M, Yu L, Garcia C, Achari G (2019) Advanced oxidation based treatment of soil wash water contaminated with sulfolane. Water (Switzerland) 11:11. https://doi.org/10.3390/w11102152

Brycki B, Małecka I, Koziróg A, Otlewska A (2017) Synthesis, structure and antimicrobial properties of novel benzalkonium chloride analogues with pyridine rings. Molecules 22:1-12. https://doi.org/10. 3390/molecules22010130

Burghoff B (2012) Foam fractionation applications. J Biotechnol 161: 126-137. https://doi.org/10.1016/j.jbiotec.2012.03.008

Camacho-Muñoz D, Martín J, Santos JL, Aparicio I, Alonso E (2014) Occurrence of surfactants in wastewater: hourly and seasonal variations in urban and industrial wastewaters from Seville (Southern Spain). Sci Total Environ 468-469:977-984. https://doi.org/10. 1016/j.scitotenv.2013.09.020

Cantarero S, Zafra-Gómez A, Ballesteros O, Navalón A, Vílchez JL, Verge C, de Ferrer JA (2011) Matrix effect study in the determination of linear alkylbenzene sulfonates in sewage sludge samples. Environ Toxicol Chem 30:813-818. https://doi.org/10.1002/etc.447

Carolei L, Gutz IGR (2005) Simultaneous determination of three surfactants and water in shampoo and liquid soap by ATR-FTIR. Talanta 66:118-124. https://doi.org/10.1016/j.talanta.2004.10.005

Cierniak D, Woźniak-Karczewska M, Parus A, Wyrwas B, Loibner AP, Heipieper HJ, Ławniczak $Ł$, Chrzanowski $Ł$ (2020) How to accurately assess surfactant biodegradation-impact of sorption on the validity of results. Appl Microbiol Biotechnol 104:1-12. https:// doi.org/10.1007/s00253-019-10202-9

Clara M, Scharf S, Scheffknecht C, Gans O (2007) Occurrence of selected surfactants in untreated and treated sewage. Water Res 41:43394348. https://doi.org/10.1016/j.watres.2007.06.027

Cloutier M, Mantovani D, Rosei F (2015) Antibacterial coatings: challenges, perspectives, and opportunities. Trends Biotechnol 33:637652. https://doi.org/10.1016/j.tibtech.2015.09.002

Cochran RE, Laskina O, Jayarathne T, Laskin A, Laskin J, Lin P, Sultana C, Lee C, Moore KA, Cappa CD, Bertram TH, Prather KA, Grassian VH, Stone EA (2016) Analysis of organic anionic surfactants in fine and coarse fractions of freshly emitted sea spray aerosol. Environ Sci Technol 50:2477-2486. https://doi.org/10. 1021/acs.est.5b04053

Collivignarelli MC, Abbà A, Bertanza G (2015) Why use a thermophilic aerobic membrane reactor for the treatment of industrial wastewater/ liquid waste? Environ Technol (United Kingdom) 36:2115-2124. https://doi.org/10.1080/09593330.2015.1021860

Collivignarelli MC, Abbà A, Bertanza G, Barbieri G (2017) Treatment of high strength aqueous wastes in a thermophilic aerobic membrane reactor (TAMR): performance and resilience. Water Sci Technol 76: 3236-3245. https://doi.org/10.2166/wst.2017.492

Collivignarelli MC, Carnevale Miino M, Baldi M, Manzi S, Abbà A, Bertanza G (2019) Removal of non-ionic and anionic surfactants from real laundry wastewater by means of a full-scale treatment system. Process Saf Environ Prot 132:105-115. https://doi.org/10. 1016/j.psep.2019.10.022

Cui L, Puerto M, López-Salinas JL, Biswal SL, Hirasaki GJ (2014) Improved methylene blue two-phase titration method for determining cationic surfactant concentration in high-salinity brine. Anal Chem 86:11055-11061. https://doi.org/10.1021/ac500767m

Cvrković-Karloci Ž, Krznarić D, Šeruga M, Ćosović B (2011) Simple electrochemical determination of surface-active substances in natural waters. Int J Electrochem 2011:1-7. https://doi.org/10.4061/ $2011 / 416834$

da Silva SW, Klauck CR, Siqueira MA, Bernardes AM (2015) Degradation of the commercial surfactant nonylphenol ethoxylate by advanced oxidation processes. J Hazard Mater 282:241-248. https://doi.org/10.1016/j.jhazmat.2014.08.014

De La Fuente L, Acosta T, Babay P et al (2010) Degradation of nonylphenol ethoxylate-9 (NPE-9) by photochemical advanced oxidation technologies. Ind Eng Chem Res 49:6909-6915. https://doi. org/10.1021/ie901785j

Dehghani MH, Zarei A, Yousefi M (2019) Efficiency of ultrasound for degradation of an anionic surfactant from water: surfactant determination using methylene blue active substances method. MethodsX 6:805-814. https://doi.org/10.1016/j.mex.2019.03.028

Delanghe B, Mekras CI, Graham NJD (1991) Aqueous Ozonation Of Surfactants: A Review. Ozone Sci Eng 13:639-673. https://doi. org/10.1080/01919512.1991.10555707

Di Nica V, Gallet J, Villa S, Mezzanotte V (2017) Toxicity of quaternary ammonium compounds (QACs) as single compounds and mixtures to aquatic non-target microorganisms: experimental data and predictive models. Ecotoxicol Environ Saf 142:567-577. https://doi.org/ 10.1016/j.ecoenv.2017.04.028

Dimeski G, Badrick T, John AS (2010) Ion selective electrodes (ISEs) and interferences-a review. Clin Chim Acta 411:309-317. https:// doi.org/10.1016/j.cca.2009.12.005

Domene X, Ramírez W, Solà L, Alcañiz JM, Andrés P (2009) Soil pollution by nonylphenol and nonylphenol ethoxylates and their effects to plants and invertebrates. J Soils Sediments 9:555-567. https://doi. org/10.1007/s11368-009-0117-6

Esteban García AB, Szymański K, Mozia S, Sánchez Pérez JA (2021) Treatment of laundry wastewater by solar photo-Fenton process at pilot plant scale. Environ Sci Pollut Res 28:8576-8584. https://doi. org/10.1007/s11356-020-11151-x

Fei X, Li W, Zhu S, Liu L, Yang Y (2018) Simultaneous treatment of dye wastewater and surfactant wastewater by foam separation: experimental and mesoscopic simulation study. Sep Sci Technol 53:1604 1610. https://doi.org/10.1080/01496395.2017.1406951

Ganiyu SO, Vieira dos Santos E, Tossi de Araújo Costa EC, MartínezHuitle CA (2018a) Electrochemical advanced oxidation processes (EAOPs) as alternative treatment techniques for carwash wastewater reclamation. Chemosphere 211:998-1006. https://doi.org/10.1016/ j.chemosphere.2018.08.044

Ganiyu SO, Zhou M, Martínez-Huitle CA (2018b) Heterogeneous electro-Fenton and photoelectro-Fenton processes: a critical review 
of fundamental principles and application for water/wastewater treatment. Appl Catal B Environ 235:103-129

Gao D, Li Z, Guan J, Li Y, Ren N (2014) Removal of surfactants nonylphenol ethoxylates from municipal sewage-comparison of an A/O process and biological aerated filters. Chemosphere 97:130 134. https://doi.org/10.1016/j.chemosphere.2013.10.083

Gao D, Li Z, Guan J, Liang H (2017) Seasonal variations in the concentration and removal of nonylphenol ethoxylates from the wastewater of a sewage treatment plant. J Environ Sci (China) 54:217-223. https://doi.org/10.1016/j.jes.2016.02.005

Gao Q, Wu F, Hu J, Chen W, Zhang X, Guo X, Wang B, Wang X (2020) Chemical composition-dependent removal of cationic surfactants by carbon nanotubes. Sci Total Environ 716:137017. https://doi.org/10. 1016/j.scitotenv.2020.137017

Garcia-Rodríguez A, Matamoros V, Fontàs C, Salvadó V (2014) The ability of biologically based wastewater treatment systems to remove emerging organic contaminants - a review. Environ Sci Pollut Res 21:11708-11728. https://doi.org/10.1007/s11356-0132448-5

Garcia MT, Campos E, Marsal A, Ribosa I (2008) Fate and effects of amphoteric surfactants in the aquatic environment. Environ Int 34: 1001-1005. https://doi.org/10.1016/j.envint.2008.03.010

Gartshore J, Lim YC, Cooper DG (2000) Quantitative analysis of biosurfactants using Fourier transform infrared (FT-IR) spectroscopy. Biotechnol Lett 22:169-172. https://doi.org/10.1023/A: 1005670031432

Ge F, Xu Y, Zhu R, Yu F, Zhu M, Wong M (2010) Joint action of binary mixtures of cetyltrimethyl ammonium chloride and aromatic hydrocarbons on Chlorella vulgaris. Ecotoxicol Environ Saf 73:16891695. https://doi.org/10.1016/j.ecoenv.2010.06.003

Gerlache M, Kauffmann JM, Quarin G, Vire JC, Bryant GA, Talbot JM (1996) Electrochemical analysis of surfactants: an overview. Talanta 43:507-519. https://doi.org/10.1016/0039-9140(95)01787-9

Gheorghe S, Lucaciu I, Paun I et al (2013) Ecotoxicological behavior of some cationic and amphoteric surfactants (biodegradation, toxicity and risk assessment). Biodegrad - Life Sci. https://doi.org/10.5772/ 56199

Ghosh DC, Sen PK, Pal B (2020) Influence of anions and micelle and submicellar aggregates on the alkaline hydrolysis of malachite green: tensiometric, spectrophotometric, and kinetic investigations. J Phys Chem B 124:2048-2059. https://doi.org/10.1021/acs.jpcb. 9b11936

Gönder ZB, Balcıoğlu G, Vergili I, Kaya Y (2017) Electrochemical treatment of carwash wastewater using $\mathrm{Fe}$ and $\mathrm{Al}$ electrode: technoeconomic analysis and sludge characterization. J Environ Manag 200:380-390. https://doi.org/10.1016/j.jenvman.2017.06.005

Gupta VK, Carrott PJM, Ribeiro Carrott MML, Suhas (2009) Low-cost adsorbents: growing approach to wastewater treatment a review. Crit Rev Environ Sci Technol 39:783-842

Hampel M, Mauffret A, Pazdro K, Andalusian JB (2012) Anionic surfactant linear alkylbenzene sulfonates (LAS) in sediments from the Gulf of Gdansk (southern Baltic Sea, Poland) and its environmental implications. Environ Monit Assess 184:6013-6023. https://doi.org/ 10.1007/s10661-011-2399-6

Harkins D, Introduction I (1947) Determination of the critical concentration for micelle formation in solutions of colloidal electrolytes by the spectral change of a dye 1

Heidarinejad Z, Rahmanian O, Fazlzadeh M, Heidari M (2018) Enhancement of methylene blue adsorption onto activated carbon prepared from Date Press Cake by low frequency ultrasound. J Mol Liq 264:591-599. https://doi.org/10.1016/j.molliq.2018.05.100

Hao M, Qiu M, Yang H, Hu B, Wang X (2021) Recent advances on preparation and environmental applications of MOF-derived carbons in catalysis. Sci Total Environ 2021(760):143333

Hibberd A, Maskaoui K, Zhang Z, Zhou JL (2009) An improved method for the simultaneous analysis of phenolic and steroidal estrogens in water and sediment. Talanta 77:1315-1321. https://doi.org/10.1016/ j.talanta.2008.09.006

Hossain N, Bhuiyan MA, Pramanik BK, Nizamuddin S, Griffin G (2020) Waste materials for wastewater treatment and waste adsorbents for biofuel and cement supplement applications: a critical review. J Clean Prod 255:120261. https://doi.org/10.1016/j.jclepro.2020. 120261

Hu N, Li Y, Yang C, Wu Z, Liu W (2019) In-situ activated nanoparticle as an efficient and recyclable foam stabilizer for enhancing foam separation of LAS. J Hazard Mater 379:120843. https://doi.org/10. 1016/j.jhazmat.2019.120843

Im SH, Jeong YH, Ryoo JJ (2008) Simultaneous analysis of anionic, amphoteric, nonionic and cationic surfactant mixtures in shampoo and hair conditioner by RP-HPLC/ELSD and LC/MS. Anal Chim Acta 619:129-136. https://doi.org/10.1016/j.aca.2008.03.058

Ivanković T, Hrenović J (2010) Surfactants in the environment. Arh Hig Rada Toksikol 61:95-110. https://doi.org/10.2478/10004-1254-612010-1943

Jain P, Sharma M, Dureja P, Sarma PM, Lal B (2017) Bioelectrochemical approaches for removal of sulfate, hydrocarbon and salinity from produced water. Chemosphere 166:96-108. https://doi.org/10.1016/ j.chemosphere.2016.09.081

Jardak K, Drogui P, Daghrir R (2016) Surfactants in aquatic and terrestrial environment: occurrence, behavior, and treatment processes. Environ Sci Pollut Res 23:3195-3216. https://doi.org/10.1007/ s11356-015-5803-x

Jiménez-díaz I, Ballesteros O, Zafra-gómez A et al (2010) Chemosphere new sample treatment for the determination of alkylphenols and alkylphenol ethoxylates in agricultural soils. Chemosphere 80: 248-255. https://doi.org/10.1016/j.chemosphere.2010.04.032

Jozanović M, Sakač N, Karnaš M, Medvidović-Kosanović M (2019) Potentiometric sensors for the determination of anionic surfactants-a review. Crit Rev Anal Chem 0:1-23. https://doi.org/ 10.1080/10408347.2019.1684236, 51

Jurado E, Fernández-Serrano M, Núñez-Olea J et al (2002) Comparison and use of methods for the determination of non-ionic surfactants in biodegradation processes. Tenside Surfactant Deterg 39:154-159

Kargosha K, Ahmadi SH, Mansourian M, Azad J (2008) Simultaneous determination of one nonionic and two anionic surfactants using Fourier transform infrared spectrometry and multivariate analysis. Talanta 75:589-593. https://doi.org/10.1016/j.talanta.2007.11.065

Khan S, Sayed M, Sohail M, et al (2018) Chapter 6 - advanced oxidation and reduction processes. In: Advances in Water Purification Techniques: Meeting the Needs of Developed and Developing Countries. pp 135-164

Kim TH, Yu S, Choi Y, Jeong TY, Kim SD (2018) Profiling the decomposition products of perfluorooctane sulfonate (PFOS) irradiated using an electron beam. Sci Total Environ 631-632:1295-1303. https://doi.org/10.1016/j.scitotenv.2018.03.055

Koparal AS, Önder E, Öğütveren ÜB (2006) Removal of linear alkylbenzene sulfonate from a model solution by continuous electrochemical oxidation. Desalination 197:262-272. https://doi.org/ 10.1016/j.desal.2005.12.024

Kortner TM, Mortensen AS, Hansen MD, Arukwe A (2009) Neural aromatase transcript and protein levels in Atlantic salmon (Salmo salar) are modulated by the ubiquitous water pollutant, 4nonylphenol. Gen Comp Endocrinol 164:91-99. https://doi.org/10. 1016/j.ygcen.2009.05.009

Kruszelnicka I, Ginter-Kramarczyk D, Wyrwas B, Idkowiak J (2019) Evaluation of surfactant removal efficiency in selected domestic wastewater treatment plants in Poland 09 Engineering 0907 Environmental Engineering. J Environ Health Sci Eng 17:257264. https://doi.org/10.1007/s40201-019-00387-6

Kurrey R, Deb MK, Shrivas K, Nirmalkar J, Sen BK, Mahilang M, Jain VK (2020) A KBr-impregnated paper substrate as a sample probe for the enhanced ATR-FTIR signal strength of anionic and non- 
ionic surfactants in an aqueous medium. RSC Adv 10:4042840441. https://doi.org/10.1039/d0ra07286a

Kurrey R, Mahilang M, Deb MK, Shrivas K (2019) Analytical approach on surface active agents in the environment and challenges. Trends Environ Anal Chem 21:e00061

Lara-Martín PA, Gómez-Parra A, González-Mazo E (2006) Development of a method for the simultaneous analysis of anionic and non-ionic surfactants and their carboxylated metabolites in environmental samples by mixed-mode liquid chromatography-mass spectrometry. J Chromatogr A 1137:188-197. https://doi.org/10. 1016/j.chroma.2006.10.009

Lara-Martín PA, Gómez-Parra A, Sanz JL, González-Mazo E (2010) Anaerobic degradation pathway of linear alkylbenzene sulfonates (IAS) in sulfate-reducing marine sediments. Environ Sci Technol 44:1670-1676. https://doi.org/10.1021/es9032887

Lara-Martín PA, González-Mazo E, Brownawell BJ (2012) Environmental analysis of alcohol ethoxylates and nonylphenol ethoxylate metabolites by ultra-performance liquid chromatography-tandem mass spectrometry. Anal Bioanal Chem 402:2359-2368. https://doi.org/10.1007/s00216-011-5449-6

Larson RJ, Rothgeb TM, Shimp RJ, Ward TE, Ventullo RM (1993) Kinetics and practical significance of biodegradation of linear alkylbenzene sulfonate in the environment. J Am Oil Chem Soc 70:645-657. https://doi.org/10.1007/BF02640999

León VM, González-Mazo E, Gómez-Parra A (2000) Handling of marine and estuarine samples for the determination of linear alkylbenzene sulfonates and sulfophenylcarboxylic acids. J Chromatogr A 889: 211-219. https://doi.org/10.1016/S0021-9673(00)00569-0

Lewis E, Lewis E (2018) REACH Regulation. Sustainaspeak:219-219. https://doi.org/10.4324/9781315270326-156

Li R, Gao B, Sun J, Yue Q (2018a) Coagulation behavior of kaolinanionic surfactant simulative wastewater by polyaluminum chloride-polymer dual coagulants. Environ Sci Pollut Res 25: 7382-7390. https://doi.org/10.1007/s11356-017-1073-0

Li X, Doherty AC, Brownawell B, Lara-Martin PA (2018b) Distribution and diagenetic fate of synthetic surfactants and their metabolites in sewage-impacted estuarine sediments. Environ Pollut 242:209-218. https://doi.org/10.1016/j.envpol.2018.06.064

Li Z, Liu L, Song S, Guo S, Kuang H, Xu C (2014) Development of an enzyme-linked immunosorbent assay for octylphenol. Food Agric Immunol 25:397-410. https://doi.org/10.1080/09540105.2013. 821597

Li Q, Chen Z, Wang H, Yang H, Wen T, Wang S, Hu B, Wang X (2021) Removal of organic compounds by nanoscale zero-valent iron and its composites. Sci Total Environ 792:148546

Liu X, Ma R, Zhuang L, Hu B, Chen J, Liu X, Wang X (2021) Recent developments of doped g-C3N4 photocatalysts for the degradation of organic pollutants. Crit Rev Environ Sci Technol 51:751-790

Liu X, Pohl CA, Weiss J (2006) New polar-embedded stationary phase for surfactant analysis. J Chromatogr A 1118:29-34. https://doi.org/ 10.1016/j.chroma.2006.03.080

Lobachev AL, Kolotvin AA (2006) Identification and quantitative determination of priority nonionic and amphoteric surfactants in raw materials and detergent compositions by high-performance liquid chromatography, thin-layer chromatography, and UV spectrometry. J Anal Chem 61:622-629. https://doi.org/10.1134/ S1061934806070021

Loyo-Rosales JE, Schmitz-Afonso I, Rice CP, Torrents A (2003) Analysis of octyl- and nonylphenol and their ethoxylates in water and sediments by liquid chromatography/tandem mass spectrometry. Anal Chem 75:4811-4817. https://doi.org/10.1021/ac0262762

Lu F, Astruc D (2020) Nanocatalysts and other nanomaterials for water remediation from organic pollutants. Coord Chem Rev 408:213180. https://doi.org/10.1016/j.ccr.2020.213180

Lunar L, Rubio S, Pérez-Bendito D (2004) Differentiation and quantification of linear alkyl benzenesulfonate isomers by liquid chromatography-ion-trap mass spectrometry. J Chromatogr A 1031:17-25. https://doi.org/10.1016/j.chroma.2003.08.071

Luo S, Fang L, Wang X, Liu H, Ouyang G, Lan C, Luan T (2010) Determination of octylphenol and nonylphenol in aqueous sample using simultaneous derivatization and dispersive liquid-liquid microextraction followed by gas chromatography-mass spectrometry. J Chromatogr A 1217:6762-6768. https://doi.org/10.1016/j. chroma.2010.06.030

Lv Y, Lv JW, Zhou JL, Shen J (2014) Surfactant accelerating leaching of uranium ores. In: Advanced Materials Research. pp 166-170

Ma Q, Zhang Y, Zhai J, Chen X, du Z, Li W, Bai H (2019) Characterization and analysis of non-ionic surfactants by supercritical fluid chromatography combined with ion mobility spectrometry-mass spectrometry. Anal Bioanal Chem 411:27592765. https://doi.org/10.1007/s00216-019-01777-3

Mansourian M, Ahmadi SH, Nazifi M, Kargosha K (2019) Simultaneous determination of two alcohols and one anionic surfactant in commercial liquid cleaners using partial least square regression by Fourier transform infrared spectrometry. Tenside Surfactant Deterg 56:25-34. https://doi.org/10.3139/113.110602

Martínez-Huitle CA, Panizza M (2018) Electrochemical oxidation of organic pollutants for wastewater treatment. Curr Opin Electrochem 11:62-71. https://doi.org/10.1016/j.coelec.2018.07.010

Masadome T, Imato T, Asano Y (1999) End-point detection of the potentiometric titration of anionic polyelectrolytes using an anionic surfactant-selective plasticized poly (vinyl chloride) membrane electrode and an anionic surfactant as a marker ion. Fresenius J Anal Chem 363:241-245. https://doi.org/10.1007/s002160051181

Menger R, Funk E, Borch T, Henry C (2021) Sensors for detecting perand polyfluoroalkyl substances (PFAS): a critical review of development challenges, current sensors, and commercialization obstacles. Water Res 129133:129133. https://doi.org/10.1016/j.cej.2021. 129133

Merino F, Rubio S, Pérez-Bendito D (2004) Evaluation and optimization of an on-line admicelle-based extraction-liquid chromatography approach for the analysis of ionic organic compounds. Anal Chem 76: 3878-3886. https://doi.org/10.1021/ac049736v

Mohajerani M, Mehrvar M, Ein-Mozaffari F (2010) Recent achievements in combination of ultrasonolysis and other advanced oxidation processes for wastewater treatment. Int J Chem React Eng 8:8. https:// doi.org/10.2202/1542-6580.2216

Mohammadi MJ, Takdastan A, Jorfi S, Neisi A, Farhadi M, Yari AR, Dobaradaran S, Khaniabadi YO (2017) Electrocoagulation process to chemical and biological oxygen demand treatment from carwash grey water in Ahvaz megacity, Iran. Data Br 11:634-639. https:// doi.org/10.1016/j.dib.2017.03.006

Morales-Muñoz S, Luque-García JL, Luque De Castro MD (2004) Screening method for linear alkylbenzene sulfonates in sediments based on water Soxhlet extraction assisted by focused microwaves with on-line preconcentration/derivatization/detection. J Chromatogr A 1026:41-46. https://doi.org/10.1016/j.chroma.2003. 11.047

Motteran F, Nascimento RF, Nadai BM, Titato GM, dos Santos Neto ÁJ, Silva EL, Varesche MBA (2019) Identification of anionic and nonionic surfactant and recalcitrants compounds in commercial laundry wastewater by GC-MS analysis after anaerobic fluidized bed reactor treatment. Water Air Soil Pollut 230:230. https://doi.org/10.1007/ s11270-019-4357-9

Moura AGL, Centurion VB, Okada DY, Motteran F, Delforno TP, Oliveira VM, Varesche MBA (2019) Laundry wastewater and domestic sewage pilot-scale anaerobic treatment: microbial community resilience regarding sulfide production. J Environ Manag 251: 109495. https://doi.org/10.1016/j.jenvman.2019.109495

Mungray AK, Kumar P (2009) Fate of linear alkylbenzene sulfonates in the environment: a review. Int Biodeterior Biodegrad 63:981-987. https://doi.org/10.1016/j.ibiod.2009.03.012 
Nagarnaik PM, Mills MA, Boulanger B (2010) Concentrations and mass loadings of hormones, alkylphenols, and alkylphenol ethoxylates in healthcare facility wastewaters. Chemosphere 78:1056-1062. https://doi.org/10.1016/j.chemosphere.2009.11.019

Nascimento COC, Veit MT, Palácio SM, Gonçalves GC, Fagundes-Klen MR (2019) Combined application of coagulation/flocculation/sedimentation and membrane separation for the treatment of laundry wastewater. Int J Chem Eng 2019:1-13. https://doi.org/10.1155/ $2019 / 8324710$

Nasiri M, Ahmadzadeh H, Amiri A (2020) Sample preparation and extraction methods for pesticides in aquatic environments: a review. TrAC - Trends Anal Chem 123:115772

Naumczyk J, Marcinowski P, Bogacki J (2017) Treatment of highly polluted cosmetic wastewater. Environ Prot Eng 44:25-40. https:// doi.org/10.5277/epe170203

Ncibi MC, Gaspard S, Sillanpää M (2015) As-synthesized multi-walled carbon nanotubes for the removal of ionic and non-ionic surfactants. J Hazard Mater 286:195-203. https://doi.org/10.1016/j.jhazmat. 2014.12.039

Nesměrák K, Němcová I (2006) Determination of critical micelle concentration by electrochemical means. Anal Lett 39:1023-1040. https://doi.org/10.1080/00032710600620302

Olkowska E, Ruman M, Kowalska A, Polkowska Z (2013) Determination of surfactants in environmental samples. part iii. non-ionic compounds4. Ecol Chem Eng S 20:449-461. https://doi. org/10.2478/eces-2013-0033

Olkowska E, Ruman M, Polkowska Z (2014) Occurrence of surface active agents in the environment. J Anal Methods Chem 2014:115. https://doi.org/10.1155/2014/769708

Ostos FJ, Lebrón JA, Moyá ML, Bernal E, Flores A, Lépori C, Maestre Á, Sánchez F, López-Cornejo P, López-López M (2021) Potentiometric study of carbon nanotube/surfactant interactions by ion-selective electrodes. Driving forces in the adsorption and dispersion processes. Int J Mol Sci 22:1-12. https://doi.org/10.3390/ ijms 22020826

Palmer M, Hatley H (2018) The role of surfactants in wastewater treatment: Impact, removal and future techniques: a critical review. Water Res 147:60-72. https://doi.org/10.1016/j.watres.2018.09.039

Pan YP, Tsai SW (2008) Solid phase microextraction procedure for the determination of alkylphenols in water by on-fiber derivatization with N-tert-butyl-dimethylsilyl-N-methyltrifluoroacetamide. Anal Chim Acta 624:247-252. https://doi.org/10.1016/j.aca.2008.06.039

Patil R, Jain V (2021) Andrographolide: a review of analytical methods. J Chromatogr Sci 59:191-203. https://doi.org/10.1093/chromsci/ bmaa091

Petrie B, Barden R, Kasprzyk-Hordern B (2015) A review on emerging contaminants in wastewaters and the environment: current knowledge, understudied areas and recommendations for future monitoring. Water Res 72:3-27. https://doi.org/10.1016/j.watres.2014.08. 053

Petrović M, Barceló D (2000) Determination of anionic and nonionic surfactants, their degradation products, and endocrine-disrupting compounds in sewage sludge by liquid chromatography/mass spectrometry. Anal Chem 72:4560-4567. https://doi.org/10.1021/ ac000306o

Pinto ACS, de Barros GL, de Melo RAC et al (2017) Carwash wastewater treatment by micro and ultrafiltration membranes: effects of geometry, pore size, pressure difference and feed flow rate in transport properties. J Water Process Eng 17:143-148. https://doi.org/10. 1016/j.jwpe.2017.03.012

Priac A, Morin-Crini N, Druart C, Gavoille S, Bradu C, Lagarrigue C, Torri G, Winterton P, Crini G (2017) Alkylphenol and alkylphenol polyethoxylates in water and wastewater: a review of options for their elimination. Arab J Chem 10:S3749-S3773. https://doi.org/ 10.1016/j.arabjc.2014.05.011
Ramprasad C, Philip L (2016) Surfactants and personal care products removal in pilot scale horizontal and vertical flow constructed wetlands while treating greywater. Chem Eng J 284:458-468. https:// doi.org/10.1016/j.cej.2015.08.092

Rawat S, Joshi G, Annapurna D, Arunkumar AN, N. Karaba N (2016) Standardization of DNA extraction method from mature dried leaves and ISSR-PCR conditions for $<\mathrm{i}>$ Melia dubia $<\mathrm{i}>\mathrm{Cav}$. - a fast growing multipurpose tree species. Am J Plant Sci 07:437-445. https://doi.org/10.4236/ajps.2016.73037

Rico-Rico Á, Droge STJ, Widmer D, Hermens JLM (2009) Freely dissolved concentrations of anionic surfactants in seawater solutions: optimization of the non-depletive solid-phase microextraction method and application to linear alkylbenzene sulfonates. J Chromatogr A 1216:2996-3002. https://doi.org/10.1016/j.chroma.2009.01.090

Robards K, Prenzler PD, Tucker G, Swatsitang P, Glover W (1999) Phenolic compounds and their role in oxidative processes in fruits. Food Chem 66:401-436. https://doi.org/10.1016/S0308-8146(99) 00093-X

Rodriguez Boluarte IA, Andersen M, Pramanik BK, Chang CY, Bagshaw S, Farago L, Jegatheesan V, Shu L (2016) Reuse of car wash wastewater by chemical coagulation and membrane bioreactor treatment processes. Int Biodeterior Biodegrad 113:44-48. https:// doi.org/10.1016/j.ibiod.2016.01.017

Roslan RN, Hanif NM, Othman MR, Azmi WNFW, Yan XX, Ali MM, Mohamed CAR, Latif MT (2010) Surfactants in the sea-surface microlayer and their contribution to atmospheric aerosols around coastal areas of the Malaysian Peninsula. Mar Pollut Bull 60: 1584-1590. https://doi.org/10.1016/j.marpolbul.2010.04.004

Sak-Bosnar M, Madunić-Čačić D, Grabarić Z, Grabarić B (2015) Potentiometric determination of anionic and nonionic surfactants in surface waters and wastewaters. In: Handbook of Environmental Chemistry. Springer Verlag, pp 157-176

Saleh TA (2020a) Trends in the sample preparation and analysis of nanomaterials as environmental contaminants. Trends in Environmental Analytical Chemistry 28e00101-10.1016/ j.teac.2020.e00101

Saleh TA (2020b) Characterization determination and elimination technologies for sulfur from petroleum: Toward cleaner fuel and a safe environment. Trends in Environmental Analytical Chemistry 25e00080-10.1016/j.teac.2020.e00080

Saleh TA (2020c) Nanomaterials: Classification properties and environmental toxicities. Environmental Technology \& Innovation 20101067-10.1016/j.eti.2020.101067

Saleh TA (2021) Protocols for synthesis of nanomaterials polymers and green materials as adsorbents for water treatment technologies. Environmental Technology \& Innovation 24101821-10.1016/ j.eti.2021.101821

Sander S, Henze G (1997) AC-voltammetric determination of the total concentration of nonionic and anionic surfactants in aqueous systems. Electroanalysis 9:243-246. https://doi.org/10.1002/elan. 1140090311

Scaria J, Nidheesh PV, Kumar MS (2020) Synthesis and applications of various bimetallic nanomaterials in water and wastewater treatment. J Environ Manag 259:110011. https://doi.org/10.1016/j.jenvman. 2019.110011

Scholz F (2015) Voltammetric techniques of analysis: the essentials. ChemTexts 1:1-24. https://doi.org/10.1007/s40828-015-0016-y

Scholz N, Behnke T, Resch-Genger U (2018) Determination of the critical micelle concentration of neutral and ionic surfactants with fluorometry, conductometry, and surface tension - a method comparison. J Fluoresc 28:465-476. https://doi.org/10.1007/s10895-0182209-4

Shah I, Adnan R, Wan Ngah WS, Mohamed N (2015) Iron impregnated activated carbon as an efficient adsorbent for the removal of methylene blue: regeneration and kinetics studies. PLoS One 10: e0122603. https://doi.org/10.1371/journal.pone.0122603 
Sirés I, Brillas E (2012) Remediation of water pollution caused by pharmaceutical residues based on electrochemical separation and degradation technologies: a review. Environ Int 40:212-229. https://doi. org/10.1016/j.envint.2011.07.012

Siyal AA, Shamsuddin MR, Low A, Rabat NE (2020) A review on recent developments in the adsorption of surfactants from wastewater. J Environ Manag 254:109797. https://doi.org/10.1016/j.jenvman. 2019.109797

Srinet SS, Basak A, Ghosh P, Chatterjee J (2017) Separation of anionic surfactant in paste form from its aqueous solutions using foam fractionation. J Environ Chem Eng 5:1586-1598. https://doi.org/10. 1016/j.jece.2017.02.008

Sriwiriyarat T, Wongvian R, Kuhakaew S (2017) Selection of coagulant with consideration of sludge characteristics for treatment of industrial wastewater containing high strength mixed surfactants. Chiang Mai J Sci 44:1654-1668

Szymanski A, Jaroszynski T, Jeszka P, Lukaszewski Z (1996) Tensammetric studies of biodegradation of Marlipal 1618/25 in the river water die-away test. Water Res 30:2465-2471. https:// doi.org/10.1016/0043-1354(96)00137-6

Taghavi K, Pendashteh A, Mozhdehi SP (2017) Combined fenton-like oxidation and aerobic MBBR biological processes for treatment of the wastewater of detergent industries. Desalin Water Treat 77:206214. https://doi.org/10.5004/dwt.2017.20866

Tang Y, Pan J, Sun T, Hu Y, du Z (2020) Ultra-high performance supercritical fluid chromatography combined with quadrupole time-offlight mass spectrometry for the characterization of pentaerythritol fatty acid esters. Rapid Commun Mass Spectrom 34:34. https://doi. org/10.1002/rcm.8664

Tsai PC, Ding WH (2004) Determination of alkyltrimethylammonium surfactants in hair conditioners and fabric softeners by gas chromatography-mass spectrometry with electron-impact and chemical ionization. In: Journal of Chromatography A, 1027, 1-2, 2004, 103-108, doi.org/10.1016/j.chroma.2003.10.047

Valizadeh S, Younesi H, Bahramifar N (2016) Highly mesoporous $\mathrm{K} 2 \mathrm{CO} 3$ and $\mathrm{KOH} /$ activated carbon for SDBS removal from water samples: batch and fixed-bed column adsorption process. Environ Nanotechnology, Monit Manag 6:1-13. https://doi.org/10.1016/j. enmm.2016.06.005

Van De Voorde A, Lorgeoux C, Gromaire MC, Chebbo G (2012) Analysis of quaternary ammonium compounds in urban stormwater samples. Environ Pollut 164:150-157. https://doi.org/10.1016/j. envpol.2012.01.037

van Os NM, Haak JR, Rupert LAM (1993) Introduction. PhysicoChemical Prop Sel Anionic, Cationic Nonion Surfactants 1-8. https://doi.org/10.1016/b978-0-444-89691-9.50004-4

Villar M, Callejón M, Jiménez JC, Alonso E, Guiráum A (2007) Optimization and validation of a new method for analysis of linear alkylbenzene sulfonates in sewage sludge by liquid chromatography after microwave-assisted extraction. Anal Chim Acta 599:92-97. https://doi.org/10.1016/j.aca.2007.07.065

Wang J, Du Z, Wang W, Xue W (2012) Titrimetric determination of anionic surfactant content in anionic/nonionic surfactant mixture solution by anionic surfactant selective electrode. Turk J Chem 36: 545-555. https://doi.org/10.3906/kim-1109-42

Watson MK, Tezel U, Pavlostathis SG (2012) Biotransformation of alkanoylcholines under methanogenic conditions. Water Res 46: 2947-2956. https://doi.org/10.1016/j.watres.2012.03.021
Wu S, Liang F, Hu D, Li H, Yang W, Zhu Q (2020) Determining the critical micelle concentration of surfactants by a simple and fast titration method. Anal Chem 92:4259-4265. https://doi.org/10. 1021/acs.analchem.9b04638

Yamamoto K, Oka M, Murakami H (2002) Spectrophotometric determination of trace ionic and non-ionic surfactants based on a collection on a membrane filter as the ion associate of the surfactant with erythrosine B. Anal Chim Acta 455:83-92. https://doi.org/10. 1016/S0003-2670(01)01560-4

Yamane M, Toyo T, Inoue K, Sakai T, Kaneko Y, Nishiyama N (2008) Aquatic toxicity and biodegradability of advanced cationic surfactant APA-22 compatible with the aquatic environment. J Oleo Sci 57:529-538. https://doi.org/10.5650/jos.57.529

Yamini Y, Feizi N, Moradi M (2019) Surfactant-based extraction systems. Liquid-Phase Extraction, In, pp 209-239

Yang K, Jing Q, Wu W, Zhu L, Xing B (2010) Adsorption and conformation of a cationic surfactant on single-walled carbon nanotubes and their influence on naphthalene sorption. Environ Sci Technol 44:681-687. https://doi.org/10.1021/es902173v

Ying GG (2006) Fate, behavior and effects of surfactants and their degradation products in the environment. Environ Int 32:417-431. https://doi.org/10.1016/j.envint.2005.07.004

Yao L, Yang H, Chen Z, Qiu M, Hu B, Wang X (2021) Bismuth oxychloride-based materials for the removal of organic pollutants in wastewater. Chemosphere. 2021(273):128576

Zanoletti A, Federici S, Borgese L, Bergese P, Ferroni M, Depero LE, Bontempi E (2017) Embodied energy as key parameter for sustainable materials selection: the case of reusing coal fly ash for removing anionic surfactants. J Clean Prod 141:230-236. https://doi.org/10. 1016/j.jclepro.2016.09.070

Zhang C, Valsaraj KT, Constant WD, Roy D (1999) Aerobic biodegradation kinetics of four anionic and nonionic surfactants at sub- and supra-critical micelle concentrations (CMCs). Water Res 33:115124. https://doi.org/10.1016/S0043-1354(98)00170-5

Zhang C, Wen H, Huang Y, Shi W (2017) Adsorption of anionic surfactants from aqueous solution by high content of primary amino crosslinked chitosan microspheres. Int J Biol Macromol 97:635641. https://doi.org/10.1016/j.ijbiomac.2017.01.088

Zhou Z, Liu X, Lin C et al (2019) Persulfate-based advanced oxidation processes (AOPs) for organic-contaminated soil remediation: a review impacts of land use change on diffuse nitrogen pollution and nitrous oxide emission under climate warming View project Persulfate-based advanced oxida. Chem Eng J 372:836-851. https://doi.org/10.1016/j.cej.2019.04.213

Zhu FJ, Ma WL, Xu TF, Ding Y, Zhao X, Li WL, Liu LY, Song WW, Li YF, Zhang ZF (2018) Removal characteristic of surfactants in typical industrial and domestic wastewater treatment plants in Northeast China. Ecotoxicol Environ Saf 153:84-90. https://doi.org/10.1016/j. ecoenv.2018.02.001

Zhu Z, Li Z, Hao Z, Chen J (2003) Direct spectrophotometric determination of alkylphenol polyethoxylate nonionic surfactants in wastewater. Water Res 37:4506-4512. https://doi.org/10.1016/S00431354(03)00379-8

Publisher's note Springer Nature remains neutral with regard to jurisdictional claims in published maps and institutional affiliations. 